\title{
From Nationally Bounded to Pan-European Inequalities? On the Importance of Foreign Countries as Reference Groups
}

October 2005

Order No:

SP I 2005 - 204

ISSN 1612-3468

Research Area: Employment, Social Structure, and Welfare State

Research Unit: Inequality and Social Integration 
We would like to thank Jens Alber for his encouragement, guidance and luminous critisism. We also would like to thank our colleagues Petra Böhnke, Christoph Hilbert and Wolfgang Keck for valuable suggestions, and Marion Obermaier for careful assistance in producing the paper. Earlier versions of the paper have been presented at various occasions, i.e. the ARS brown-bag seminar at the WZB, the meeting of the "Methoden-Sektion" of the German Society for Sociology (DGS) in Konstanz, the conference "Europeanisation of social inequalities" in Bamberg, and the $1^{\text {st }}$ Conference of the European Association for Survey Research (EASR) in Barcelona. Thanks to all participants of these meetings for the pleasant discussions. 


\section{Summary}

In sociology, the appropriateness of national approaches for understanding social inequality in today's societies is being increasingly questioned, and EU-wide approaches are advocated instead. In this paper, we link the growing debate about national or EU-wide approaches to reference group theory, investigating whether comparisons with foreign countries influence levels of individual life satisfaction. Our results indicate that, on the one hand, more people can be assumed to have a national frame of reference than a broader international one; on the other hand, among those who do have an idea of how average people in other countries live, cross-border comparisons certainly influence people's satisfaction with life. Upward comparisons in particular are important: The more people feel personally deprived, relative to other countries, the less satisfied they are with their lives. In contrast, the feeling of relative gratification has a much smaller impact on life satisfaction, and often no impact at all. This leads us to conclude that EU-wide approaches to inequality do make sense, but that there is also no need to jettison national approaches completely. 


\section{Contents}

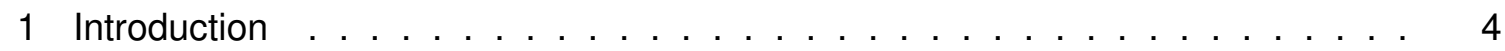

2 Reference group theory and international reference groups $\ldots \ldots \ldots$

3 Euromodule data . . . . . . . . . . . . . . . . . . . . . . . . . . 10

4 The prevalence of cross-national comparisons . . . . . . . . . . . . . . . . . . 14

4.1 The share of missing answers . . . . . . . . . . . . . . . . . . . . 14

4.2 How people compare living conditions across nations . . . . . . . . . . . . . 17

4.3The gross impact of cross-border comparisons on life satisfaction . . . . . . 19

4.4The relevance of upward comparisons . . . . . . . . . . . . . . . . 23

4.5Robustness of results . . . . . . . . . . . . . . . . . . . . . . . 25

5 Discussion and conclusion . . . . . . . . . . . . . . . . . . . . . 27

A Euromodule sampling information . . . . . . . . . . . . . . . . . . . 30

B Regression tables . . . . . . . . . . . . . . . . . . . . . . . 31

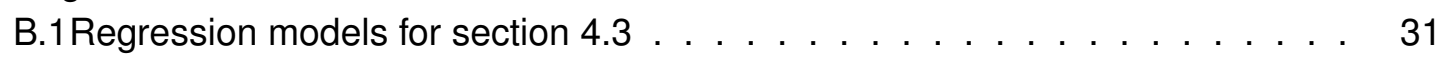

B.2Regression models for section $4.4 \mid \ldots \ldots \ldots \ldots \ldots$ 
In their recent book, Beck and Grande (2004) heavily criticise inequality research for being blind to the European dimension. The concentration on national societies, their argument goes, has distorted our perception of inequalities by overemphasising inequalities within countries and downplaying the much larger inequalities between European countries. However, this distortion caused by the traditional "container" model of society (Beck 2002: 390) will gradually disappear as a result of Europeanisation. Awareness of the huge disparities between countries is growing and causing the poorer nations to demand a bigger share of the welfare cake. Thus European integration can be expected to lead to the emergence of European-wide distribution conflicts that overlap with those already apparent at national level.

The need for an expanded approach has also been advocated by Fahey (2005). His starting point is the paradox that although the average living standard is much lower in Poland than in Ireland, a larger share of the Irish population is regarded as poor according to official EU statistics. The simple reason is that poverty is measured against national thresholds. The poor are those at the margins of the society they live in, no matter whether that society as a whole is rich or poor. However, since living standards across Europe are very unequal, this approach hardly seems appropriate from an EU perspective: "While poverty measured in this way may make sense in national terms, its meaning becomes strained when applied without qualification at an EU level" (Fahey 2005). Fahey advocates an additional EU-wide approach to poverty based on a European threshold similar to those already used in EU regional policy. This would substantially change our account of who is considered to be rich and poor in the enlarged EU.

These two examples may illustrate the paradigmatic shift currently being discussed by sociologists. Either as an addition to (Fahey) or replacement for (Beck) nation-centred sociology, inequality research is meant to investigate the pan-European distribution of resources, living conditions and related assessments. One can well imagine EU-wide poverty measures, income distributions, and stratification models, with European society as a whole (the EU's social space) replacing individual European societies as the unit of analysis. In such models, nationality would simply appear as another explanatory variable.

However, first things first. Just as the appropriateness of the container model of society can be questioned, so doubt can also be cast on the appropriateness of pan-European approaches. It is perfectly possible that they are mere statistical abstractions, rather than accurate reflections of the everyday experiences of ordinary citizens. In particular, it could be argued that people are still not internationally oriented and that they compare themselves to friends, neighbours and colleagues at home rather than to people living in other countries. What are the crucial conditions that would make EU-wide approaches useful? Essentially, citizens frame of reference would have to extend their horizons well beyond the national realm, perceiving themselves, or their countries, as part of a larger European or even international stratification system. Furthermore, the perception-whether false or 
correct — of being advantaged or disadvantaged within this system would have to play an important role in individuals' evaluation of their own life circumstances. Thus the reference groups to which people relate themselves are the litmus test for the appropriateness of EU-wide approaches.

This paper aims to demonstrate the usefulness of reference group theory in European inequality research. It also attempts to feed empirical evidence into the debate. With the help of recent mass surveys conducted in Germany, Hungary and Turkey, we examine empirically the idea that perceptions of relativities between societies matter for individual life satisfaction. Our guiding research question can be formulated as follows. Are people's perceptions of and comparisons with living conditions in other nations impacting on their personal life satisfaction, either positively or negatively? Our results indicate that, on the one hand, more people can be assumed to have a national frame of reference than a broader international one; on the other hand, among those who do have an idea of how average people in other countries live, cross-border comparisons certainly influence people's satisfaction with life. This leads us to conclude that EU-wide approaches to inequality do make sense, but that there is also no need to jettison national approaches completely.

We proceed in four steps. Section 2 places the issue in the broader context of reference group theory; the database and the main indicators are introduced in section 3 , in section 4 we present the empirical results; finally, the main findings are discussed, with reference to the appropriateness of national and EU-wide approaches. 


\section{Reference group theory and international reference groups}

Although reference group theory has a long and distinguished pedigree, the issue of international reference groups is rather new. In "The American Soldier", Stouffer et al. (1949) found that soldiers' feelings of deprivation and dissatisfaction were less related to the actual degree of hardship they experienced than to the situation of the unit or group to which they compared themselves. In order to make sense of many of their findings, the concept of "relative deprivation" was introduced as an intermediate stage between the "objective" situation and subjective evaluation of the same. In 1951, the rich material provided by "The American Soldier" was systematised and related to the broader "reference group concept" by Merton and Kitt (1950). The basic idea of reference group theory is that people compare themselves with other individuals or groups when evaluating their own situation or conduct. "Reference group" denotes a group a person uses as a comparison point in making evaluations of himself or others (Hyman 1968; Merton and Kitt 1950; Kelly 1968). By reviewing several cases from "The American Soldier", Merton and Kitt (1950: 53) pointed out that relative deprivation can be regarded as a particular concept within the much broader reference group theory.

The comparisons people make were assumed to involve different frames of reference. First, individuals may compare their situations with others with whom they are in close association (membership groups or in-groups), or with others with whom they do not have sustained relations (non-membership groups or out-groups). Second, individuals may compare themselves with others who are of the same social status (or category), or of different social status (or category). Clearly, there are many possible reference groups. However, the authors of "The American Soldier", as well as many others (e.g. Festinger 1968), assumed that the yardstick people most commonly used was associates of the same status, primarily the in-group of friends and associates. If a group's standing is so high or so low that it is not meaningful to the individual, it will hardly serve as a yardstick for comparison. Proximity and perceived similarity is seen as key factors in the selection of a reference group; this is essentially consistent with Mead's claim that membership groups influence individual behaviour much more strongly than non-membership groups do (Mead 1934, 56). This assumption has guided much of the empirical research. However, Merton and Kitt are perfectly right in saying that for sociologists it is much more puzzling why and under what conditions individuals orientate themselves towards outgroups.

"Ultimately, of course, the theory must be generalised to the point where it can account for both membership- and non-membership-orientations, but immediately its major task is to search out the processes through which individuals relate themselves to groups to which they do not belong" (Merton and Kitt 1950: 50).

They developed two ideas as to the conditions under which people are outward-looking. 
If a group's system of stratification is viewed as illegitimate or if individuals are isolated from the other members of their in-groups, then they are likely to take the situation of an out-group as the context for evaluating their own lot. Thus legitimacy of rewards and social integration prevent people from looking to see whether the grass is greener on the other side of the fence.

Do Merton and Kitt consider the possibility that people might select a foreign outgroup as frame of reference? Given their formalistic language, the term out-group is by no means restricted to the national realm. However, among the many examples they cite, there is no mention of any international reference groups, i.e. individuals, groups or collectivities located in another country. The failure to address this issue leads us to assume that, for the founders of the concept, it seemed almost natural that comparisons would be made within rather than between societies. Empirical research in the field of welfare and subjective well-being has by and large adopted this nation-centred view (e.g. Easterlin 1974; Veenhoven 1991; Diener et al. 1992). In a review article summarising the state of the art (Schwarz and Strack 1999), none of the research cited investigated the issue of cross-border reference groups. The international dimension did not appear either in Michalos' (1985) multiple discrepancy theory, nor in Hagerty's (1998) attempt to unify liveability and comparison theory.

We have not come across any study that systematically explores the impact of crossnational frames of reference. Research has concentrated on national comparisons with friends, neighbours, colleagues and social classes but largely neglected any possible international dimension. One exception is the seminal study "How nations see each other" (Buchanan and Cantril 1953), which, however, originated from a different background, namely foreign policy and international relations. Here, answers to the following question are reported: "Which country in the world gives you the best chance of leading the kind of life you would like to lead?" Respondents were free to choose their own nation or any other nation. In America and Australia, which safely escaped the devastation of WW II, nine out of ten respondents chose their own country, whereas in the devastated European countries, only between one third and one half chose their own country, and many named the U.S. as the country offering them the best life chances.

Another example is a French study from 1951 (Stern and Keller 1968), in which 198 unstructured interviews about what constituted "a satisfactory standard of living" were scrutinised for every reference group explicitly mentioned by respondents. On average, the French made reference to 3.6 groups, most of them "we-groups". And among the "they"-statements, only a few refer to other countries:

\footnotetext{
"The only national groups mentioned were the 'Americans' and the 'French'. The former was mentioned mostly by upper class respondents, always in a context of resentment of the greater and more widespread availability of comforts in America" (Stern and Keller 1968: 212).
}

These findings lend some support to the idea that an international orientation might be a phenomenon confined to the upper strata of society (or might have been in the early 1950s at least) and that people look to rich rather than poor countries when thinking about their 
standard of living. This hypothesis is perfectly consistent with one of the key findings of empirical research, namely that upward comparisons, especially the feeling of relative deprivation, have a much greater impact on how people think about their situation than downward comparisons. However, Stern and Keller did not discuss such ideas; instead they quickly concluded that international reference groups were "of little value for reference group theory".

Almost fifty years elapsed before interest was reawakened in how people see living conditions in other countries. One crucial factor behind this re-launch was the growth of social reporting activities at the supranational level. One of the issues particularly debated is whether Europeans liken their own situation to that of populations living in other countries. Do cross-border comparisons influence how individuals think and feel about their own conditions? The following suggestion was recently made:

"In judging the adequacy of their personal situations, Europeans seem to have an uncanny grasp of where their societies stand in the international (or at least European) hierarchy of economic development and to take that standing into account in arriving at subjective evaluations of their personal circumstances" (Fahey and Smyth 2003: 17).

Fahey speculates that the frames of reference people use to judge their situation include cross-national as well as national elements (Fahey 2005). Hence, the high contentment found in rich societies could be produced (in part) by citizens' knowledge (or impression) that they have a privileged position in international society, while the discontent in poorer societies could stem (again in part) from citizens' knowledge (or impression) that they live in relative deprivation. However, no empirical account is given.

Nevertheless, such speculations seem not to have been simply plucked from the air. For example, migrants tend to move from poor, insecure countries into rich and stable democracies, which can be seen as proof that people compare their own lot not only with that of groups within their own society, but also cross-nationally, and with severe consequences. Some people flee their own country and try to make a better living somewhere else. Sociologists are observing the spread of consumer culture from the West to other parts of the world (Ger and Belk 1996). Stimulated by global mass media, tourism and advertising, people around the globe want the same luxury goods the citizens of the wealthy OECD countries enjoy. Keyfitz (1992) claims that there now exists a standard package of goods that people across the world want to possess in order not to feel deprived. However, the definition of this standard package might be based on exaggerated stereotypes of "Western" consumption patterns (Ger and Belk 1996: 58), and the finding that Turks have a more extravagant notion of what constitutes a decent standard of living than Swiss or Germans. Akçay (2005) suggests this may indeed be the case. Cross-national comparisons might also be stimulated by the processes of European integration, whereby the member states are forming a common social space. EU policy subdivides the member states into net contributors to the EU budget and net receivers, revealing which are the rich and which the poor member states.

In the following, we test the hypothesis that people's perceptions of and comparisons with living conditions in other nations impact on their personal life satisfaction, either 
positively or negatively. In order not to overload the paper, we focus on the population as $a$ whole, leaving the idea of differential reference groups for old and young age cohorts, the less or more highly educated and rich and poor segments of society for a future exercise. 


\section{$3 \quad$ Euromodule data}

In order to analyse the extent to which cross-border comparisons of living conditions matter for people's subjective well-being, it is necessary to utilise data containing information on

- people's subjective well-being,

- people's own living conditions or a general rating of living conditions in their own country and

- a general rating of the living conditions in at least one foreign country.

We are aware of a dataset that fulfils these requirements: the Euromodule. The Euromodule survey was developed in the course of a research initiative led by the Social Structure and Social Reporting Research Unit at the Social Science Research Center Berlin (WZB) and the "Social Indicators Group" at the Survey Research Centre Mannheim (ZUMA). The idea of the initiative was to develop a set of basic questions on objective living conditions, subjective well-being and quality of society_called Euromodule-which could be implemented in different types of ongoing surveys in the participating countries. It consists of a core part and an optional part. The Euromodule survey was conducted in 11 countries between 1999 and 2002: in Austria, Germany, Hungary, Italy, Slovenia, Spain, Sweden, Switzerland, South Africa, South Korea, and Turkey (Delhey et al. 2002). 1]

The strengths of the survey for our research are considerable. First, in its core part it provides us with a tried and tested dependent variable, namely life satisfaction (see the extract from the questionnaire in Figure 3). Life satisfaction can be seen as the most comprehensive individual assessment of living conditions. The puzzling question of who is satisfied with life and why has traditionally attracted sociologists (Inglehart 1990; Veenhoven 1999) and social-psychologists Campbell et al. (1976); Diener et al. (1999); Cummins (2002), and more recently also economists (Alesina et al. 2001; Frey and Stutzer 2002). It is dependent on life circumstances, but also on aspiration levels, preferences and comparisons (Diener et al. 1999; Inglehart 1990). Second, the optional part of the survey contains questions on respondents' ratings of their own living conditions, of those of friends and neighbours and of living conditions in nine countries, including respondents' own countries, which serve as our independent variables. It is important to note that these possible reference countries were given by the questionnaire; those surveyed were not asked open-ended questions about which foreign countries, if any, they took as yardsticks. It is also important to note that this question is framed in such a way as to compare countries by rating them individually rather than by ranking them. Respondents were asked first to rate the living conditions in their own country, then to classify the other

1 The Euromodule has been made publicly available by the Central Archive for Empirical Social Research at the University of Cologne (http://www.gesis.org/en/za/index.htm). ZA Study number is s4063. 
Figure 3.1: Euromodule questionnaire fragment

Life Satisfaction

- What do you mean, how satisfied are you at present with your life in general? (Note: respondents could answer with numbers between 0 and 10, where 0 means "completely dissatisfied" and 10 "completely satisfied".)

Living Condition of Reference Countries

- The living conditions among European countries differ quite a lot today, and we would like to get your personal evaluation. Please use these ladders, where the highest field represents very good living conditions and the lowest field stand for very bad living conditions. First, [your country]. Where on this ladder would you classify the living conditions in[your country]?

- In Comparison to [your country], where on the second ladder would you classify the living conditions in [reference country]?

(Note: The question is asked with reference to 9 reference countries, namely Switzerland, Netherlands, Sweden, France, Germany, Italy, Spain, Hungary and Poland.)

(Scales from 0 to 10 for all items)

Own Living Conditions/Living Conditions of Reference Groups within Country

- Now we would like to consider your general living conditions once more. On the following scheme you see a series of ladders. The highest fields of every ladder represent the best living conditions you can imagine; the lowest fields represent the worst living conditions you can imagine. First, to your current living conditions. Where on this ladder would you locate your current living conditions?

- And where would you classify the living conditions of the people in your neighbourhood?

- And where on the sixth ladder would you classify the living conditions of your friends?

(Scales from 0 to 10 for all items)

countries in comparison. Consequently, their own country served as a yardstick against which to rate the other countries.

Although the Euromodule was implemented in a number of countries, only two of them can be used for our purpose: Hungary and Turkey. They happen to be the countries that also implemented the optional part of the Euromodule survey. Fortunately, our list can be extended to three countries by using the 1998 German Welfare Survey, which served as a blueprint for the Euromodule survey $\left.\right|^{2}$ In our analysis, East and West Germany are kept separate because of different socialisation experiences and living conditions. This gives us, finally, four cases, and for the sake of simplicity and brevity we refer to these as countries or nations, although, of course, East and West Germany are one country and one nation. There are of course considerable differences between West Germany, East

2 The German Welfare Survey 1998 is publicly available at the Central Archive for Empirical Social Research, University of Cologne. Study number is s3398. 
Figure 3.2: Cross-national and within-country comparisons as constructed from the data, Hungary as an example

\begin{tabular}{|c|c|c|}
\hline Point of origin & $\begin{array}{l}\text { Comparison of living } \\
\text { conditions with reference } \\
\text { group }\end{array}$ & Type of comparison \\
\hline $\begin{array}{l}\text { Individual living conditions, } \\
\text { Hungarian respondents }\end{array}$ & $\begin{array}{c}\text { Switzerland } \\
\text { Netherlands } \\
\text { Sweden } \\
\text { France } \\
\text { Germany } \\
\text { Italy } \\
\text { Spain } \\
\text { Poland }\end{array}$ & Cross-national \\
\hline & $\begin{array}{c}\text { Friends } \\
\text { Neighbours } \\
\text { Co-nationals (Hungary) }\end{array}$ & Within-country \\
\hline
\end{tabular}

Germany, Hungary and Turkey in terms of living standards, culture and political history. These differences mean that we have the sort of most-dissimilar research design that is ideal for explorative research. The surveys are representative of citizens aged 18 and over, with sample sizes of between 1,000 and 4,020, with the exception of East Germany, which had a sample size of 473 .

The data can be used to construct several comparisons, in which individuals set their own situation alongside that of certain reference groups (see figure 3). Since all the ratings are measured on the same 11 point scale, they can be related to each other and thus become meaningful. For example, if a Turkish respondent assesses his own living conditions as worthy of 6 points and those in Hungary as meriting only 4, it can be concluded that he believes his living conditions are better than the average conditions in Hungary. We refer to this kind of comparison, in which individuals' own circumstances are set against their perception of living conditions in other countries (simply by subtracting one rating from the other), as cross-national comparisons. They can turn out to be favourable or unfavourable for the respondent. It should be noted, however, that there might be validity problems, because the question about personal living conditions is separated from the country evaluations and the wording of the extreme values of the scale is different (see Figure 3). However, in section 4.5 we describe some attempts to prevent us from reporting artefacts, which show convincingly that it is reasonable to have confidence in our results.

Using the same technique, we also generated within-country comparisons: how respondents evaluate their own living conditions compared to those of co-nationals, friends and neighbours. These groups certainly imply a national frame of reference $3^{3}$ The comparison with co-nationals can be seen as less valid than those with friends and neighbours, for the same technical reasons as for the cross-national comparisons.

3 Although, of course, friends might also include non-nationals, and occasionally also people in other countries. 
For each of these comparisons (eight cross-national and three within-country), we obtain a measure which can vary between -10 and 10 . Negative values indicate that the respondent rates his personal living conditions less highly than those of the reference group (relative deprivation). The measure is positive if the assessment is the other way around (relative gratification). A value of 0 indicates that a respondent believes that living conditions are on a par. 


\section{$4 \quad$ The prevalence of cross-national comparisons}

The presentation of results is organised as follows. We start with the frequency of missing answers for the comparison variables. Second, the distributions of the comparison variables are described (section 4.2). Third, the general impact of cross-national comparisons on life satisfaction is explored (section 4.3), before we turn to the issue of upward and downward comparisons (section 4.4). Finally we describe our attempts to examine how robust our results are (section 4.5).

In passing, please note that we have made considerable efforts to ensure reproducibility. All analyses are fully programmed with Stata do-files - from the very first loading of the original Euromodule data right up to the final published graph or table. The names of the Stata do-files are listed below the respective table or figure, or in footnotes. The do-files needed to replicate the analyses can be downloaded from the internet ${ }_{1}^{1}$

\subsection{The share of missing answers}

Comparing oneself with others requires some information about, or at least an image of, the lot of those others (Merton and Kitt 1950; 66). Hence if respondents have no opinion about living conditions in foreign countries, it is obvious that those countries do not serve as reference countries.

Figure 4.1 shows how many respondents were not able, for whatever reasons, to rate the foreign countries along with the other comparison variables, i.e. friends, neighbours and co-nationals (own country). Regarding the foreign countries, the proportion of missing responses varies a good deal between the four survey countries. It is highest in Hungary (up to $25 \%$ ), and lowest in West Germany (under $10 \%$ ). An ad-hoc explanation for this pattern might be familiarity: for (West) Germans, the listed countries are either neighbours (Switzerland, Netherlands, France, Poland) or popular destinations for vacations (Spain, Italy). Consequently, Germans are in a better position than Hungarians or Turks to form an idea about how life in these countries is. The familiarity argument is strengthened by the fact that East Germans have no difficulty in rating West Germany, but somewhat more difficulty in rating the foreign countries.

In most places, people find it easier to assess how friends, neighbours and co-nationals live than to judge the living conditions of people abroad. This is in line with mainstream reference group theory, which assumes that people compare themselves with close rather than with distant groups. We know much better how our associates or fellow citizens live than people elsewhere in Europe. For some ten percent to one quarter of the population, foreign countries obviously do not serve as a frame of reference. But for 75 percent to 90 percent cross-border comparisons might be relevant.

1 Point your browser to http://www.wz-berlin.de/ kohler/publications/refgroup05/index.htm or simply click on the respective filenames in the electronic version of this paper. 
Figure 4.1: Percentage of missing values by survey country and reference country

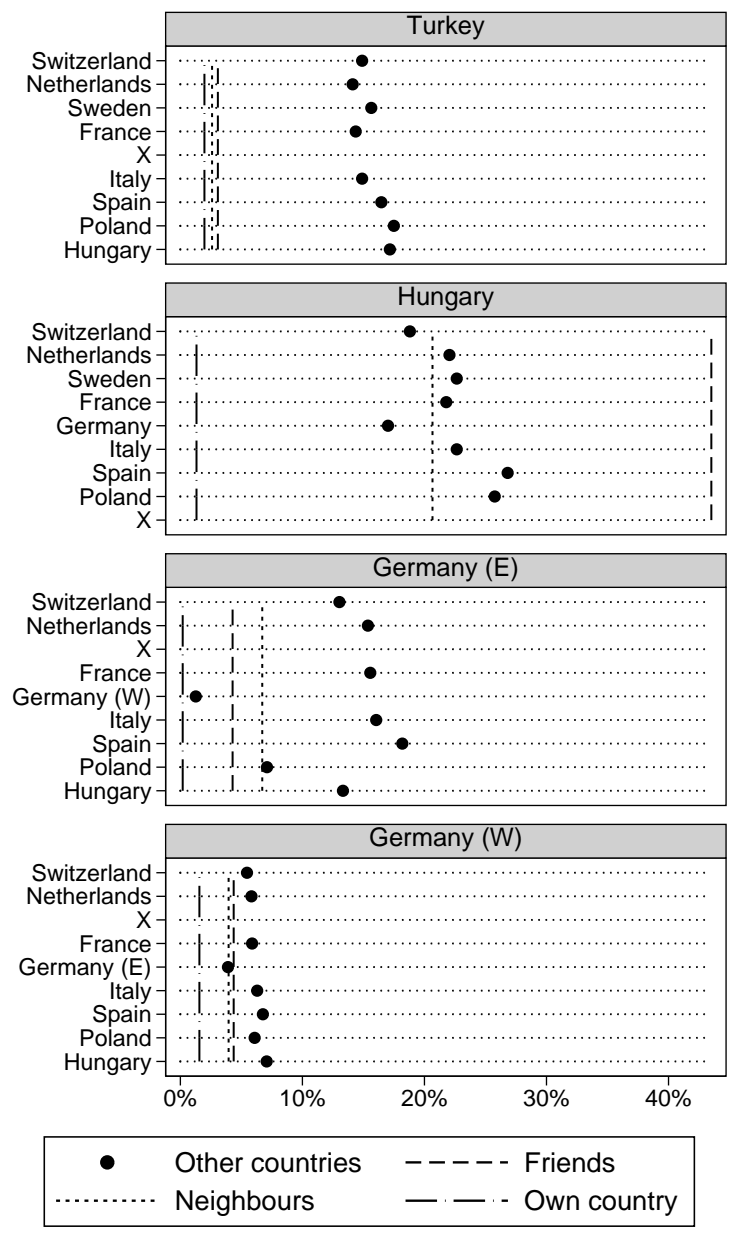

Do-File: anmiss1.do

Non-response tends to be somewhat more frequent with respect to poorer reference countries. This matches our theoretical expectation that basically people are upwardly rather than downwardly oriented. There are some exceptions to these general patterns. The most obvious case in point is Hungary. To Hungarians, neighbours seem to be as alien as foreign countries, and friends even more so. We cannot explain the extraordinary high non-response rates for neighbours here. However, we can at least provide some coincidence for the latter finding: In Hungary, every second respondent says they have no close friend outside the family (as opposed to $21 \%$ in Turkey and Germany), and 81 percent of them did not evaluate the living conditions of friends.

2 anmissHU.do 


\subsection{How people compare living conditions across nations}

Figure 4.2 shows how people locate themselves vis-à-vis other countries and in comparison to friends, neighbours and co-nationals. Box plots are used for this purpose. In box plots, a box is used to display the first and third quartile of a distribution, indicating the location and spread for the middle 50 percent of the observations. A single filled dot within the box encodes the median. The position of the median within the box gives information about the shape of the distribution. If the median is much further from one of the borders of the box than from the other, the distribution is skewed. Likewise, the solid lines besides the boxes provide summaries of spread and shape in the extremes of the distribution. The single hollow circles show outliers (Cleveland 1994: 139-143). The box plots are presented in separate panels for each survey country, and within each panel, the reference countries are sorted in ascending line according to GDP per capita (in PPP).

Most Turks feel relatively deprived compared with other countries. Even when comparing themselves to the least affluent reference country-Poland-about 75 percent of Turks believe that their personal living conditions are worse. By and large, the Hungarians share the Turkish view of relative deprivation vis-à-vis foreign nations, especially when comparing themselves to West European countries. However, a majority of Hungarians rate their living conditions as better than those of Poles. For Germany, special attention should be given to the intra-country comparison between the eastern part (former GDR) and the western part. The answers mirror the well-known economic asymmetry between the two parts, with East Germans ranking themselves lower than West Germans and West Germans ranking themselves higher than East Germans. Quite uniformly, however, East and West Germans tend to see their own personal situation as less good than in Switzerland and the Netherlands (in West Germany on a par), as by and large similar to France and as better than in Italy, Spain, Hungary and Poland.

Regarding the comparisons with friends, neighbours, and co-nationals (own country), it is well known that friends and neighbours share fairly similar social attributes (Feld 1982; Jackson 1977). Therefore one should not expect to find large differences between individuals' assessments of their own living conditions and their assessments of those of friends and neighbours. The figure does indeed show this pattern. In the same vein, the assumed difference between personal and national living conditions should not be too great on average. In fact, average living conditions in a given country can be seen as the mean of the living conditions of its individual citizens, so there should be no difference at all on average. The empirical distribution, however, shows a slight tendency on the part of respondents to rate their personal conditions slightly more highly than the average for the country. This might be explained by a general tendency among human beings to locate themselves above the mean.

Two general points are important for subsequent analysis.

- By and large, the respondents' ratings reflect quite realistically the positions of countries in the GDP league table $\mathrm{H}^{3}$

3 Even if they were unrealistic, this would not invalidate an analysis of comparisons with "international" reference groups and their possible effects on people's satisfaction with their own lives. 
Figure 4.2: Distribution of cross-national comparisons: own living conditions vs. reference group

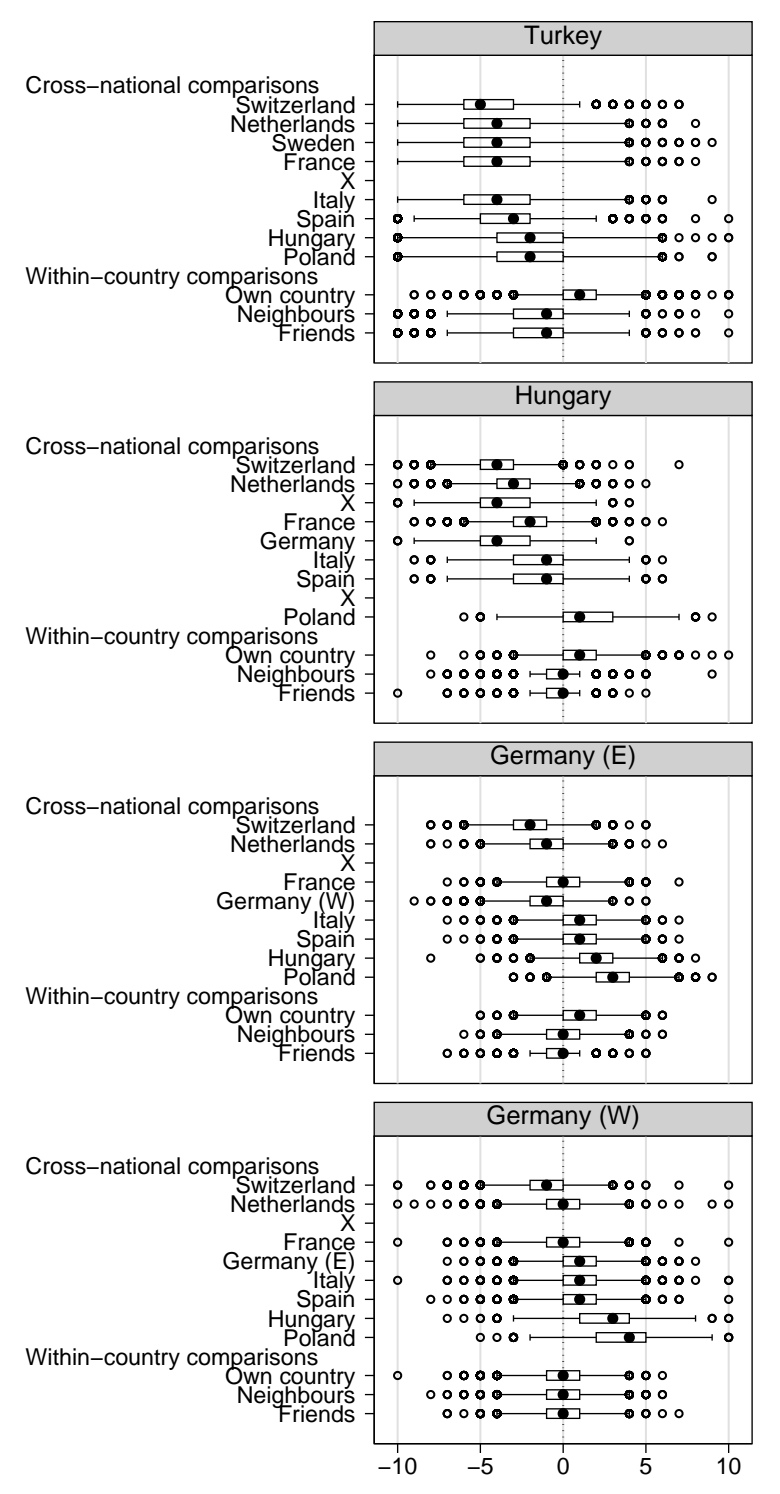

- The distributions of the comparison measures vary substantially within each survey country, and most of them seem to be fairly symmetric. Thus there is no barrier to using these variables as independent variables from the outset.

Since the measures of comparisons with close associates-friends and neighbours-are highly correlated (between 0.6 in Hungary and 0.89 in Turkey), it will hardly be possible to separate out the effects of the two groups. Hence in the subsequent analysis we combined them into a single "friends and neighbours" measure. 


\subsection{The gross impact of cross-border comparisons on life satisfaction}

So far we have investigated whether and how people are able to react to questions about living conditions in other countries. But how important are comparisons with foreign countries for subjective well-being? Do cross-border comparisons affect how satisfied people are with their lives? The general idea of our analyses is readily illustrated in Figure 4.3. which displays, for each survey country separately, the relationship between general life satisfaction and the comparison with Switzerland. The lines in the figure are nonparametric regression lines. 4

Figure 4.3: Life satisfaction by cross-national comparison with Switzerland and survey country

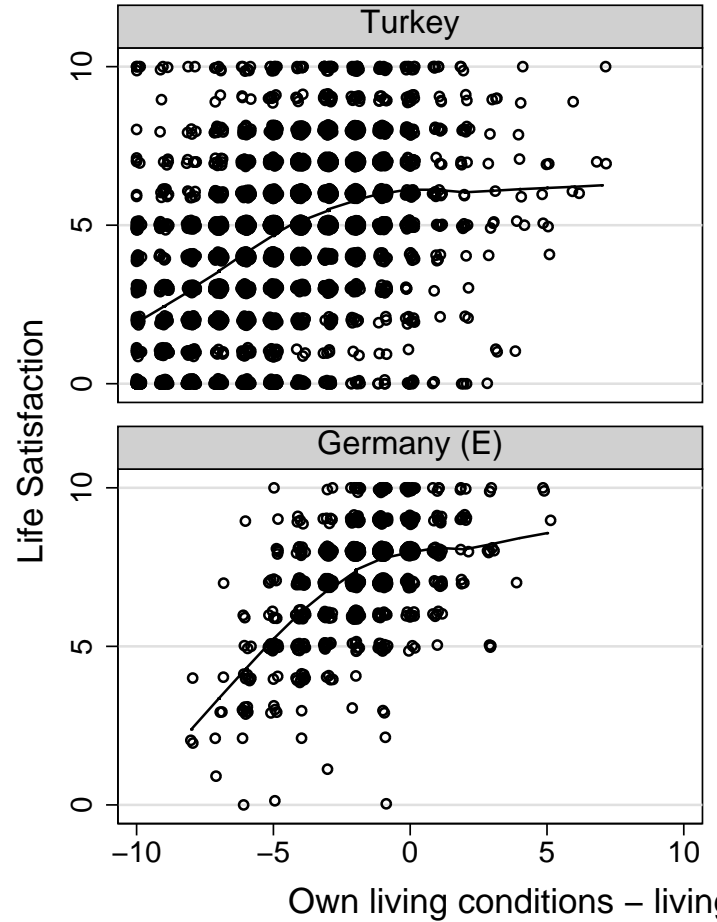

Own living conditions - living conditions Switzerland
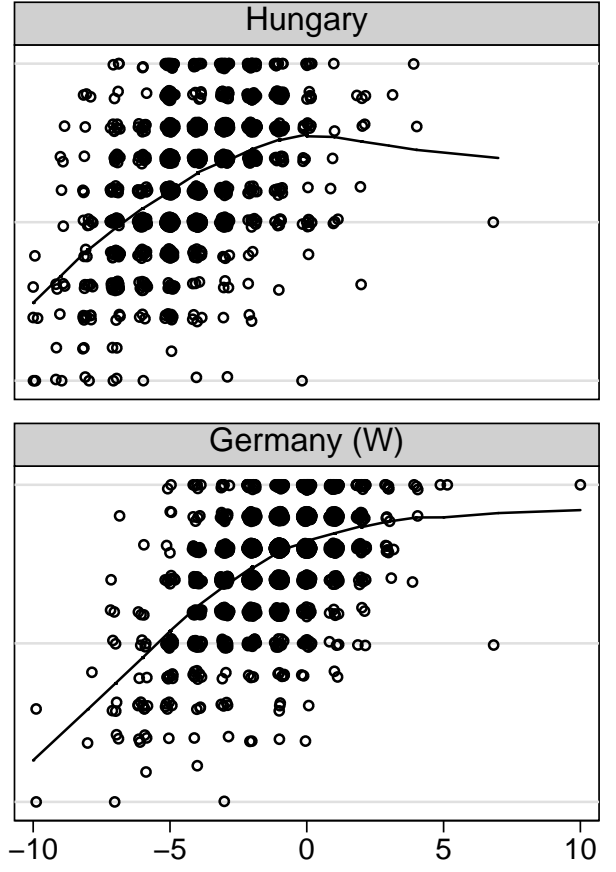

Do-File: anlsatex1.do

Life satisfaction and comparison of personal living conditions with those of the Swiss population are positively related. The better people believe their own living conditions are, compared to Switzerland, the more satisfied they are. However, this relationship seems to hold for feelings of relative deprivation only (negative values). This is further evidence that upward comparisons matter more than downward comparisons. In other words, believing

4 LOWESS with a smoothing parameter of 0.8 (Cleveland 1994). Just like the more common linear regression line, LOWESS visualises the relationship between metric variables, but without imposing an assumption of linearity. 
that we are personally worse off than people elsewhere (relative deprivation) makes us feel dissatisfied, while believing that we are personally better off than average people in other countries (relative gratification) seems not to increase our life satisfaction.

The main problem with this bivariate picture, however, is the hidden influence of respondents' absolute level of living: the outcomes of cross-border comparisons depend heavily on personal socio-economic status, and it is well known that this status also influences life satisfaction (Delhey 2004; Argyle 1999; Schyns 2002; Christoph and Noll 2003). In other words, it is perfectly possible that the relationship displayed in the figure simply reflects the relationship between individuals' objective living conditions and their consequent life satisfaction-without cross-border comparisons having any effect. The solution is to control as well as possible for socio-economic status. In the following analysis, we control for various status dimensions (standard of living, income, occupational status, employment status and education) as well as for gender, age and marital status, which might also influence life satisfaction 5 Each regression was computed with the same bloc of control variables, with each cross-border comparison included in turn. Such an analysis, however, assumes a linear relationship, which in fact is quite problematic (cf. again Figure 4.3). Consequently, the differentiation between downward and upward comparisons is lost in the regression models, but we will deal with this separately in section 4.4 .

Two properties of the Swiss example are important at this point. First, the coefficients of the control variables nicely fit the results of previous studies (Delhey 2004; Argyle 1999; Schyns 2002). We take this as a reason to have confidence in the Euromodule data. Secondly, it should be noted that in the regressions we use each reference country in turn and do not enter the within-country comparisons. The technical reason is to avoid multicollinearity, because the various comparison measures are highly correlated. Moreover, it is likely that the influences would simply neutralise each other, and hence, it would make little sense to use the various comparisons simultaneously.

We therefore calculated a series of 32 regression models (as we have four survey countries and eight across-country comparisons), using each reference country in turn. Employing the same approach, another 8 regressions were calculated in order to explore the influence of within-country comparisons (four survey countries, two within-country comparisons) ${ }^{6}$ The full results are shown in the appendix. Only the key results are presented here.

Figure 4.3 displays the unstandardised coefficients of the regression models for each of the cross-national comparisons (as dots, forming a connected line). The grey area around the dots indicates the $95 \%$ confidence interval, based on robust standard errors. Two broken horizontal lines represent the coefficients for the comparisons with friends/neighbours and co-nationals.

Do cross-border comparisons matter for individual life satisfaction? The key result is: yes, they do. The coefficient for the comparison is positive for each reference country,

5 Sampling weights were used in some of the regression models. Standard errors were calculated by applying the Huber/White/Sandwich estimator, which is robust against violations of the homoscedasticity assumption.

6 Note that we have combined the comparisons with friends and neighbours into one single variable. 
Figure 4.4: Influence of cross-national comparisons on life satisfaction by survey country
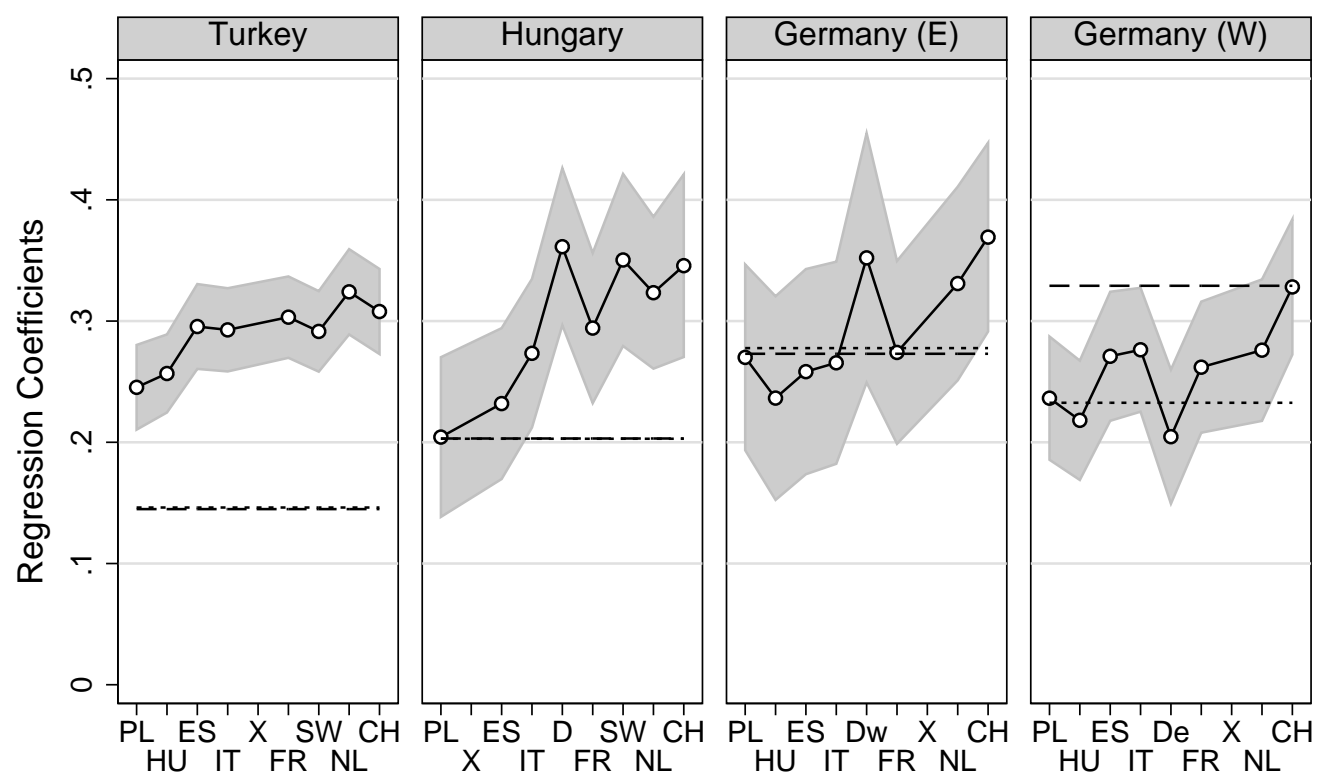

$\begin{array}{ll}\longrightarrow & \text { Other Countries } \\ \ldots \ldots \ldots+\cdots & \text { Own country }\end{array}$

Do-File: anlsat011.do

even for the lower bound of the confidence interval. The more highly individuals assess their own living conditions relative to those in the reference country, the more content people are with their lives. Obviously, foreign nations do serve as a point of reference for people's assessments of their subjective well-being. This holds true for such different populations as the Germans, Hungarians, and Turks.

The second key result is that as one moves from poor to rich reference countries (from the left to the right on the $\mathrm{x}$-axes), so the salience of the comparison increases. Usually, the impact on personal life satisfaction is higher when citizens compare themselves with Switzerland or Germany and lower when they use Poland or Hungary as a yardstick. Again the message is: upward comparisons matter more than downward comparisons, at least for life satisfaction. This rule of thumb is confirmed by the results from the two parts of Germany, since for East Germans comparison with the richer western part is more salient than comparison with the poorer East is for West Germans 7

The third key result concerns the influence of cross-national versus within-country com-

7 The latter finding could also be explained in terms of connectedness: because of the relative size of Eastern Germany and of its population (Blau 1977), East Germans are much more connected to the western part of their country than West Germans are to the eastern part (Zapf 2000). Similarly, the high salience Germany has for the Hungarians can be explained by the strong exchange relations that have traditionally existed between the two countries. 
parisons. Although caution should be exercised in comparing the effects in absolute terms, comparison in relative terms is fully justified. By and large, cross-border comparisons exert the same influence across Turkey, Hungary and the two parts of Germany. The feeling that the grass is greener on the other side of the fence has much the same impact in wealthy and less wealthy countries. However, the populations do differ considerably in the salience of in-group comparisons. Comparison with neighbours, friends and co-nationals has a small effect on life satisfaction in Turkey, a moderate effect in Hungary and a strong effect in Germany. It seems that the salience of in-group comparisons increases with national wealth. The richer a society is, the more salient the relative position within this society becomes. However, even in a wealthy society like West Germany, people do not behave like islanders, since cross-border comparisons also have an impact on life satisfaction. Thus Beck (2002) is right to question the container model of inequality research, particularly when it is applied to less affluent societies.

\subsection{The relevance of upward comparisons}

We have already advanced several pieces of evidence to support the notion that upward comparisons are more relevant than downward comparisons. Non-response is more frequent when rating poorer reference countries; cross-national comparisons influence how people feel about their lives more strongly when they compare their lot with rich countries; and less wealthy populations are less inward-looking than wealthy populations. We will now analyse the differential importance of upward and downward comparisons more directly.

To start with, let us again consider Figure 4.3 on page 20, which shows positive relationships solely for negative values of the comparison variables. Hence, for persons who believe that they are better off than average people in foreign countries it is of almost no importance how much better off they think they are. However, when people have the impression that they are doing worse than average people elsewhere, it certainly does matter how much worse they think they are doing.

Interaction terms offer a parsimonious way of tackling our problem. We first generated a dummy variable distinguishing between two groups, those who believe that they are worse off than their counterparts in the respective reference country (score 0), and those who think that they are at par or better off (score 1). We then generated an interaction term by multiplying this dummy variable with the comparison variable, and included both new variables in the regression models of the preceding section. From these models we gain three main insights.

- The effect of upward comparisons.

- The interaction effect, i.e. the amount by which the effect of the downward and upward comparisons differs.

- The effect of cross-national downward comparisons. ${ }^{8}$

8 Note that this quantity does not appear directly from the regression analysis, but can be easily calculated 
Figure 4.5: Influence of upward and downward cross-national comparisons on life satisfaction by survey country

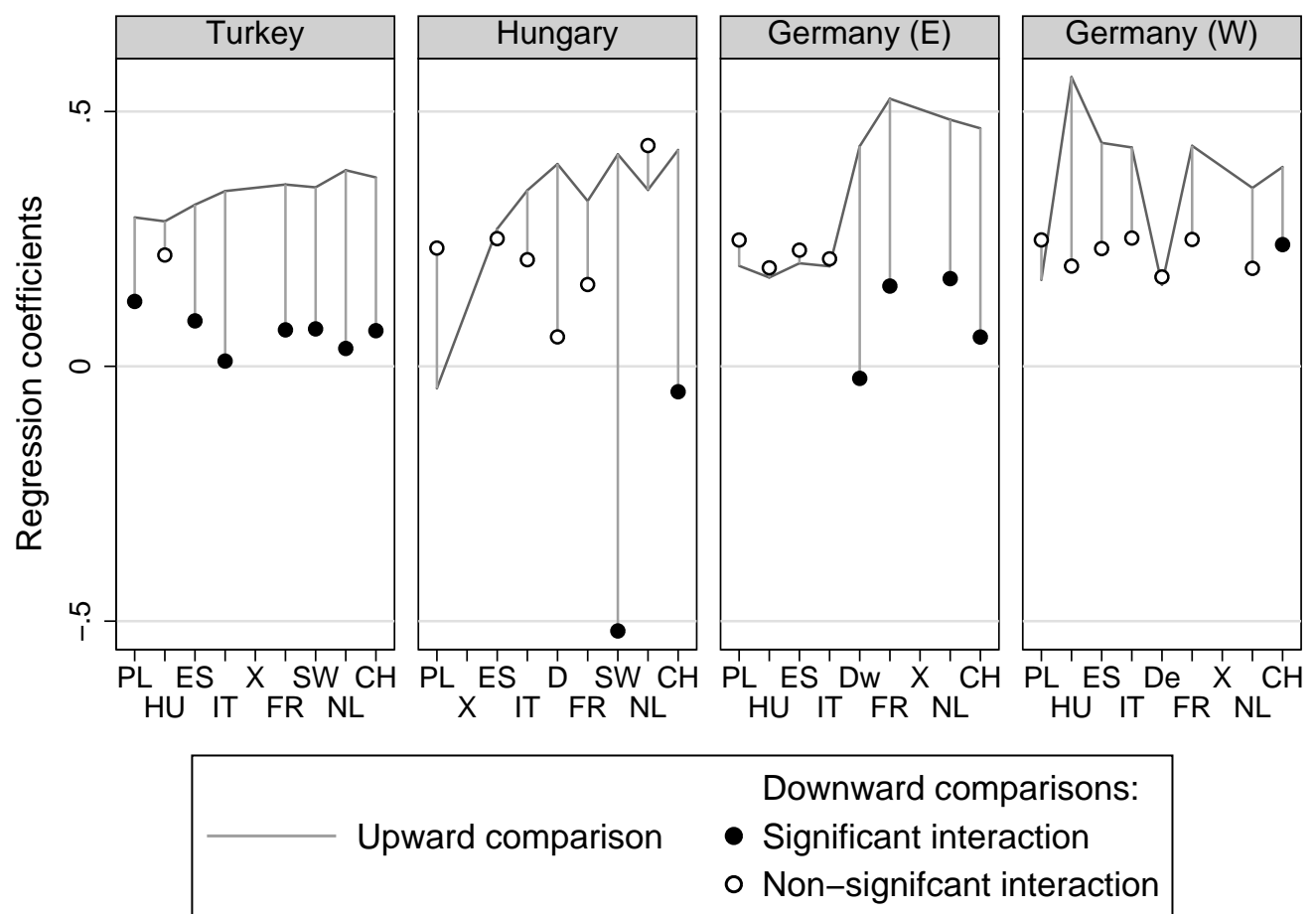

Do-File: anlsat021.do

Figure 4.4 displays the effects of upward (line) and downward (circles) comparisons. The interaction effects are implied by the length of the line connecting the two conditional effects. Black circles are used for downward comparison if the interaction effect is significant at the $5 \%$ level, while white circles are used for non-significant differences.

If upward comparisons were indeed more important, the interaction terms should be negative, implying that the coefficients for downward comparisons should be smaller than those for upward comparisons. We expect, therefore, to find the circles (downward comparisons) below the solid line (upward comparisons). By and large, the results meet our expectation. Most effects of downward comparisons are considerably below the corresponding effects of upward comparisons. Any of the seven exceptions are coefficients with non-significant interaction effects. Three of these exceptions occur when Poland is the reference country, where the effects of both upward and downward comparisons are relatively small. Hence we feel justified in concluding that, above all, upward comparisons are salient for people's well-being but that downward comparisons are not. The more people feel personally deprived, relative to other countries, the less satisfied they are with their lives. This corroborates the proverb "the grass is always greener on the other side of the

by adding the interaction effect to that of cross-national upward comparison. 
fence". Conversely, knowing that the grass is not so green on the other side does not make people more content.

\subsection{Robustness of results}

The topic of our paper breaks new ground in many respects. However, using a set of indicators that have not been used before is a risky enterprise. It is not unlikely that the substantial results produced by such an analysis are very closely tied to either the specific wording of the indicators or the specific surveys in which the indicators were used, or indeed to both. While this applies to some extent to all mass survey research, it is usually not that problematic because several datasets are available for testing hypotheses against data and for replicating results. However, with just one suitable dataset, this strategy is hardly possible for our topic.

Fortunately, the Euromodule itself offers some opportunity to check the validity of our results. There is at least one possibility, stemming from the concept of "robust dependence". Robust dependence is sometimes seen as a concept of causality. The argument is easily explained. If there are good theoretical reasons why a variable has a causal effect on a certain outcome, this effect should be measurable empirically, regardless of how well or badly the concepts involved have been measured, of the method used and of which implication of the hypotheses was adopted. Real causality should make its way into empirical observations!

We are not seeking to construct an argument here in favour of robust dependence as a concept of causality. 9 However, we do believe that the idea of robust dependence can be used as a tool to investigate causal effects. Guided by this idea, we implemented several variations of our analyses, hoping that our substantive results would hold. The variations we implemented were as follows.

- We calculated the regression models without the set of control variables 10

- We calculated the regression models using both within-country comparisons as additional control variables 11

- We used another dependent variable, namely satisfaction with one's own standard of living, instead of life satisfaction. 12

- We used yet another dependent variable, namely the difference between personal living conditions and those respondents feel entitled to (also measured on a 0-10 scale). This operationalisation measures whether a respondent believes that his actual living conditions are worse, equal to, or better than the living conditions he feels entitled to.

9 See Goldthorpe (2001) for a discussion of different concepts for causality.

10 annocontrols.do

11 anwithin.do

12 anstlivsat1.do 
- Finally, we used a different operationalisation of cross-national comparison, namely group-group comparisons. ${ }^{13}$ Here, respondents compare the living conditions in their own country with those in foreign countries. This reveals respondents' perceptions of where their own country stands in the international hierarchy, giving rise to feelings of either collective deprivation or collective gratification.

Although some of these variations give additional insights, the basic message was always the same: (1) cross-national comparisons matter and (2) people tend to be upwardoriented rather than downward-oriented.

13 anlsat011.do, anlsat021.do, anlsat031.do, anlsat041.do anlsat051.do 


\section{Discussion and conclusion}

Our starting point was the appropriateness of national or EU-wide approaches for understanding social inequality in today's societies. We linked this question to reference group theory, investigating whether comparisons with foreign countries influence levels of individual life satisfaction. Our key findings, based on survey data from West and East Germany, Hungary, and Turkey are as follows.

- As a rule of thumb, people find it easier to assess the living conditions of friends, neighbours and co-nationals than those of people abroad. Some ten percent to one quarter of the population have a national frame of reference.

For those who are able to rate living conditions in foreign countries, the following findings can be reported.

- By and large, the respondents' ratings reflect quite realistically the positions of countries in the GDP league table.

- The lower individuals perceive their own personal living conditions compared with those in the relevant reference country, the less content people are with their lives. This holds for such different populations as the Germans, Hungarians and Turks.

- Comparisons with rich countries have a greater influence than comparisons with poor countries. The more people feel personally deprived, relative to other countries, the less satisfied they are with their lives. In contrast, the feeling of relative gratification has a much smaller impact on life satisfaction, and often no impact at all.

From this it can be concluded that the claim of pan-European approaches has some validity. For the majority of citizens in very different societies, the frame of reference goes well beyond the national realm; they have an idea about how life is in other countries; and last but not least, cross-border comparisons, especially the feeling of relative deprivation against other countries, have a bearing on subjective evaluations of personal life circumstances, which was shown in this paper by measuring life satisfaction. In this respect, it makes sense to go beyond the methodological nationalism that currently characterises inequality research. Locating the position of countries or social groups within a wider European context would deepen our understanding of inequality and related feelings and evaluations.

From a supra-national policy perspective, the results are highly significant, since the recent enlargement of the European Union has drastically increased the gap between rich and poor member states, regions and citizens (Alber and Fahey 2004; Heidenreich 2003; Mau 2004). In the new member states in particular, the feeling of being relatively deprived, compared to the EU average, could lead to increasing demands for redistribution at the EU level. 
On the other hand, there is no need to jettison national approaches completely. Individuals' relative positions within the society they live in still have a bearing on status evaluation, and it is difficult to imagine that this national reference will fade away completely. Just as people are assumed to have multiple identities, so they also use multiple yardsticks, both national and international ones. Moreover, it should not be overlooked that part of the population has a national frame of reference only, and hence their behaviour and attitudes can hardly be regarded as influenced by a European or international dimension.

Our study is just a first foray into new and unfamiliar territory. It may raise more questions than it provides answers. Three of them should be addressed briefly. First, do people really use particular countries as reference points when forming their aspirations? It is perfectly possible that it is rather a vague idea about an idealised affluent society that really influences levels of aspiration. The closer particular reference countries come to this ideal, the greater their influence on life satisfaction is. In our case, Switzerland obviously comes closest to this ideal. Such a generalisation, however, would not rule out the possibility that, for historical reasons, some populations might be especially oriented towards particular countries, and that comparisons with these "significant others" might be more significant for some nations than for others.

A further question is whether the results suggest that the choice of reference groups has a specifically European rather than international dimension. The reference countries given by the questionnaire were all European and consequently there are no data available to check for the impact comparisons with non-European countries might have. Although located in a very distant part of the world, the USA in particular could turn out to be a "significant others" for Europeans. This would, however, indicate that reference groups were being internationalised rather than Europeanised. Third, both internalisation and Europeanisation refer to processes, whereas we have only cross-sectional data at hand. Thus we cannot say whether cross-border comparisons have gained in importance over time.

Finally, we take this opportunity to list some of the conditions that must be at least partially fulfilled before we can speak of the Europeanisation of inequalities when analysed from a reference group perspective. First, people should increasingly be able to rate living conditions in other European countries. Second, cross-border comparisons should have a growing impact on individuals' assessments of their own lives 11 Third, cross-border comparisons should gain in importance relative to national reference groups. And fourth, Europeans should increasingly choose European rather than non-European countries when choosing cross-border reference groups.

1 This would indicate increasing integration of EU societies (on mutual salience as a core dimension of European integration see Delhey 2004). 


\section{A Euromodule sampling information}

The Hungarian "EURÓPA" survey was conducted by TÁRKI, Budapest, in November 1999. The sample was a multi-stage probability sample of the Hungarian residental population of age 18 and above. Within regional districts 2383 addresses were selected by probablity sampling, from which the respondents were selected using the Kish selection grid. The number of realized interviews were 1510, which corresponds to a response rate of $62.7 \%$. For the German data the "Welfare Survey 1998" was used. The fieldwork of the Welfare Survey was conducted by Infratest Burke Sozialforschung, Munich, in late 1998. The sample was a stratified multi-stage sampling from the German residental population of age 18 and above. Random route sampling was used for the selection of addresses within voting districts, and the Kish selection grid for the selection of the respondent in a household. The response rate was $58.1 \%$, leading to 3042 realized interviews. Finally, the Turkish data is the "Turkish Life Standard Survey", conducted by the Middle East Technical University in the years 2001 and 2002. Respondents were selected by stratified multi-stage sampling from the Turkis population of age 16 and above. Within geographical regions, which were stratified by urbanization degree and socio-economic level, addresses where selected by systematic sampling. Overall 4020 interviews were conducted, and the response rate has been $89.3 \%$. Any of the surveys are made by personal interviews, whereby CAPI is used for the German survey. As the population universe slighly differs between the 3 surveys we excluded the foreign respondents from the German data and the respondents below the age of 18 from the Turkish data, which reduces the sample sizes to 2950 for Germany and 4001 for Turkey. 


\section{B Regression tables}

\section{B.1 Regression models for section 4.3}

Table B.1: Cross-national comparison - Turkey

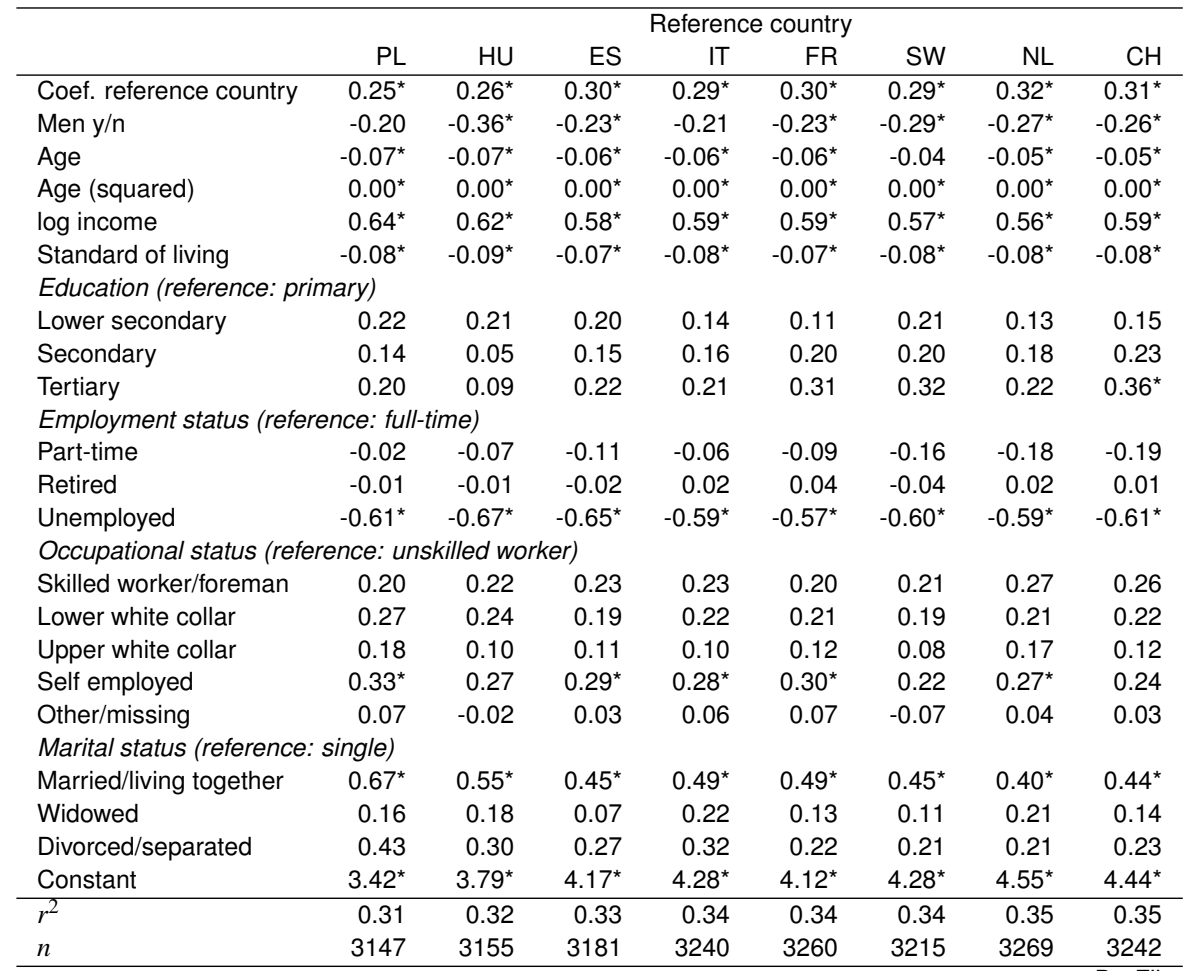


Table B.2: Cross-national comparison - Hungary

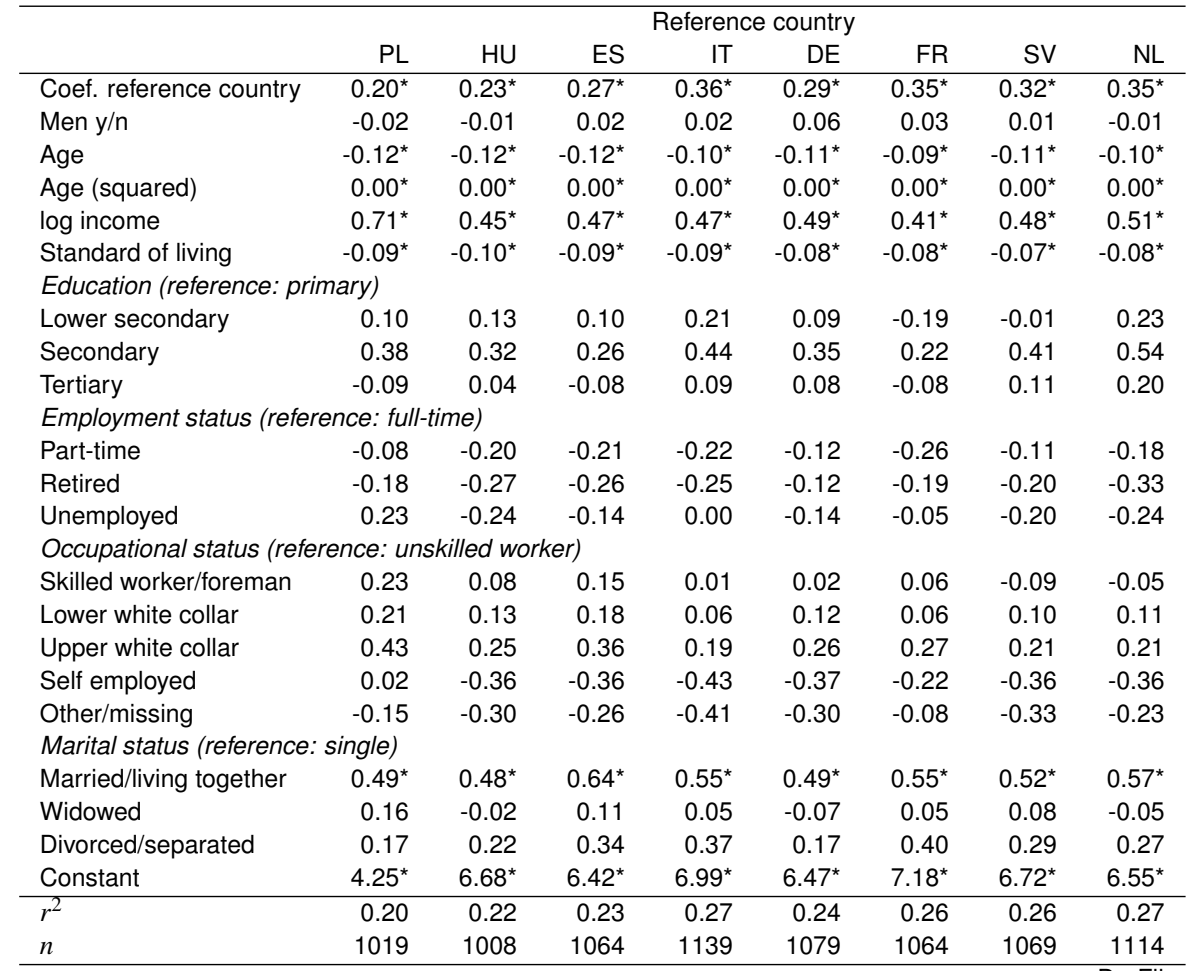

Table B.3: Cross-national comparison - Germany (E)

\begin{tabular}{|c|c|c|c|c|c|c|c|c|}
\hline & \multicolumn{8}{|c|}{ Reference country } \\
\hline & PL & $\mathrm{HU}$ & ES & IT & $\mathrm{DE}(\mathrm{W})$ & FR & NL & $\mathrm{CH}$ \\
\hline Coef. reference country & $0.27^{*}$ & $0.24^{*}$ & $0.26^{*}$ & $0.27^{*}$ & $0.35^{*}$ & $0.27^{*}$ & $0.33^{*}$ & $0.37^{*}$ \\
\hline Men $y / n$ & -0.13 & -0.11 & -0.14 & -0.14 & -0.18 & -0.10 & -0.22 & -0.09 \\
\hline Age & -0.04 & $-0.06^{*}$ & -0.04 & -0.04 & -0.05 & -0.03 & -0.03 & -0.04 \\
\hline Age (squared) & 0.00 & $0.00^{*}$ & 0.00 & 0.00 & $0.00^{*}$ & 0.00 & 0.00 & 0.00 \\
\hline log income & -0.02 & 0.00 & -0.01 & -0.11 & -0.03 & -0.03 & -0.17 & 0.08 \\
\hline Standard of living & $-0.17^{*}$ & $-0.18^{*}$ & $-0.19^{*}$ & $-0.17^{*}$ & $-0.16^{*}$ & $-0.17^{*}$ & $-0.16^{*}$ & $-0.15^{*}$ \\
\hline \multicolumn{9}{|c|}{ Education (reference: primary) } \\
\hline Lower secondary & -0.18 & -0.20 & -0.19 & -0.17 & -0.29 & -0.14 & -0.23 & -0.27 \\
\hline Secondary & -0.02 & -0.06 & -0.12 & -0.05 & -0.13 & 0.14 & 0.02 & -0.15 \\
\hline Tertiary & -0.37 & -0.41 & $-0.46^{\star}$ & -0.41 & $-0.57^{\star}$ & -0.30 & -0.39 & $-0.59^{*}$ \\
\hline \multicolumn{9}{|c|}{ Employment status (reference: full-time) } \\
\hline Part-time & -0.16 & -0.22 & -0.16 & -0.17 & -0.26 & -0.04 & -0.17 & -0.14 \\
\hline Retired & -0.27 & -0.28 & -0.37 & $-0.49^{*}$ & -0.36 & -0.38 & $-0.42^{*}$ & $-0.54^{*}$ \\
\hline Unemployed & -0.25 & -0.28 & -0.19 & -0.25 & -0.24 & -0.20 & -0.36 & -0.31 \\
\hline \multicolumn{9}{|c|}{ Occupational status (reference: unskilled worker) } \\
\hline Skilled worker/foreman & 0.31 & 0.26 & 0.31 & 0.31 & 0.33 & 0.27 & 0.26 & 0.29 \\
\hline Lower white collar & 0.48 & 0.41 & 0.32 & 0.34 & 0.39 & 0.30 & 0.24 & 0.40 \\
\hline Upper white collar & 0.33 & 0.38 & 0.28 & 0.26 & 0.34 & 0.15 & 0.23 & 0.33 \\
\hline Self employed & 0.44 & 0.38 & 0.41 & 0.43 & 0.37 & 0.37 & 0.43 & 0.50 \\
\hline Other/missing & 0.26 & 0.28 & 0.13 & 0.15 & 0.20 & 0.12 & 0.13 & 0.21 \\
\hline \multicolumn{9}{|c|}{ Marital status (reference: single) } \\
\hline Married/living together & -0.09 & 0.09 & -0.06 & -0.09 & 0.22 & -0.12 & 0.06 & 0.04 \\
\hline Widowed & -0.42 & -0.20 & -0.34 & -0.43 & -0.35 & -0.25 & -0.30 & -0.15 \\
\hline Divorced/separated & $-0.55^{*}$ & -0.39 & -0.36 & -0.51 & -0.19 & -0.45 & -0.34 & -0.26 \\
\hline Constant & $7.98^{\star}$ & $8.49^{\star}$ & $8.66^{*}$ & $9.43^{*}$ & $9.52^{*}$ & $8.76^{*}$ & $9.97^{\star}$ & $8.57^{\star}$ \\
\hline$r^{2}$ & 0.38 & 0.37 & 0.37 & 0.37 & 0.39 & 0.40 & 0.42 & 0.45 \\
\hline$n$ & 574 & 549 & 512 & 531 & 607 & 530 & 537 & 552 \\
\hline
\end{tabular}


Table B.4: Cross-national comparison - Germany (W)

\begin{tabular}{|c|c|c|c|c|c|c|c|c|}
\hline & \multicolumn{8}{|c|}{ Reference country } \\
\hline & PL & $\mathrm{HU}$ & ES & IT & $\mathrm{DE}(\mathrm{E})$ & FR & NL & $\mathrm{CH}$ \\
\hline Coef. reference country & $0.24^{*}$ & $0.22^{*}$ & $0.27^{\star}$ & $0.28^{*}$ & $0.20^{*}$ & $0.26^{*}$ & $0.28^{*}$ & $0.33^{\star}$ \\
\hline Men $y / n$ & -0.01 & -0.04 & 0.00 & -0.00 & 0.00 & 0.01 & -0.01 & -0.00 \\
\hline Age & $-0.07^{\star}$ & $-0.07^{\star}$ & $-0.07^{\star}$ & $-0.07^{\star}$ & $-0.06^{*}$ & $-0.06^{*}$ & $-0.06^{*}$ & $-0.04^{*}$ \\
\hline Age (squared) & $0.00^{*}$ & $0.00^{*}$ & $0.00^{*}$ & $0.00^{*}$ & $0.00^{*}$ & $0.00^{*}$ & $0.00^{*}$ & $0.00^{*}$ \\
\hline log income & 0.16 & 0.21 & 0.20 & 0.17 & 0.17 & 0.18 & 0.21 & 0.12 \\
\hline Standard of living & $-0.14^{*}$ & $-0.14^{*}$ & $-0.13^{*}$ & $-0.13^{*}$ & $-0.15^{*}$ & $-0.13^{*}$ & $-0.12^{*}$ & $-0.11^{*}$ \\
\hline \multicolumn{9}{|c|}{ Education (reference: primary) } \\
\hline Lower secondary & -0.04 & -0.04 & -0.03 & 0.01 & -0.03 & -0.01 & 0.05 & 0.00 \\
\hline Secondary & 0.02 & -0.01 & 0.03 & -0.00 & -0.02 & 0.01 & 0.10 & 0.07 \\
\hline Tertiary & -0.05 & -0.08 & -0.02 & -0.06 & -0.13 & -0.08 & -0.02 & -0.15 \\
\hline \multicolumn{9}{|c|}{ Employment status (reference: full-time) } \\
\hline Part-time & 0.17 & 0.14 & 0.16 & 0.14 & 0.13 & 0.14 & 0.20 & 0.23 \\
\hline Retired & 0.03 & 0.03 & 0.04 & 0.04 & 0.06 & 0.08 & 0.05 & 0.06 \\
\hline Unemployed & $-0.86^{*}$ & $-0.97^{\star}$ & $-0.81^{*}$ & $-0.84^{*}$ & $-0.93^{*}$ & $-0.82^{*}$ & $-0.88^{*}$ & $-0.89^{*}$ \\
\hline \multicolumn{9}{|c|}{ Occupational status (reference: unskilled worker) } \\
\hline Skilled worker/foreman & 0.07 & 0.06 & 0.14 & 0.03 & 0.08 & 0.15 & 0.10 & 0.10 \\
\hline Lower white collar & 0.02 & 0.05 & 0.12 & 0.07 & 0.12 & 0.12 & 0.05 & 0.05 \\
\hline Upper white collar & 0.08 & 0.10 & 0.10 & 0.09 & 0.12 & 0.11 & 0.10 & 0.20 \\
\hline Self employed & 0.20 & 0.27 & 0.40 & 0.33 & 0.23 & 0.32 & 0.33 & 0.30 \\
\hline Other/missing & 0.13 & 0.09 & 0.11 & 0.11 & 0.14 & 0.15 & 0.10 & 0.11 \\
\hline \multicolumn{9}{|c|}{ Marital status (reference: single) } \\
\hline Married/living together & $0.43^{*}$ & $0.49^{*}$ & $0.49^{*}$ & $0.42^{*}$ & $0.43^{*}$ & $0.42^{*}$ & $0.39^{*}$ & $0.35^{\star}$ \\
\hline Widowed & -0.03 & -0.04 & 0.09 & -0.01 & 0.06 & -0.04 & -0.08 & -0.15 \\
\hline Divorced/separated & -0.21 & -0.12 & -0.09 & -0.23 & -0.20 & -0.19 & -0.20 & -0.21 \\
\hline Constant & $7.08^{\star}$ & $7.05^{\star}$ & $7.29^{*}$ & $7.59^{\star}$ & $7.59^{*}$ & $7.63^{*}$ & $7.36^{*}$ & $8.11^{*}$ \\
\hline$r^{2}$ & 0.34 & 0.34 & 0.35 & 0.36 & 0.31 & 0.34 & 0.34 & 0.38 \\
\hline$n$ & 1117 & 1106 & 1108 & 1112 & 1144 & 1117 & 1117 & 1125 \\
\hline
\end{tabular}




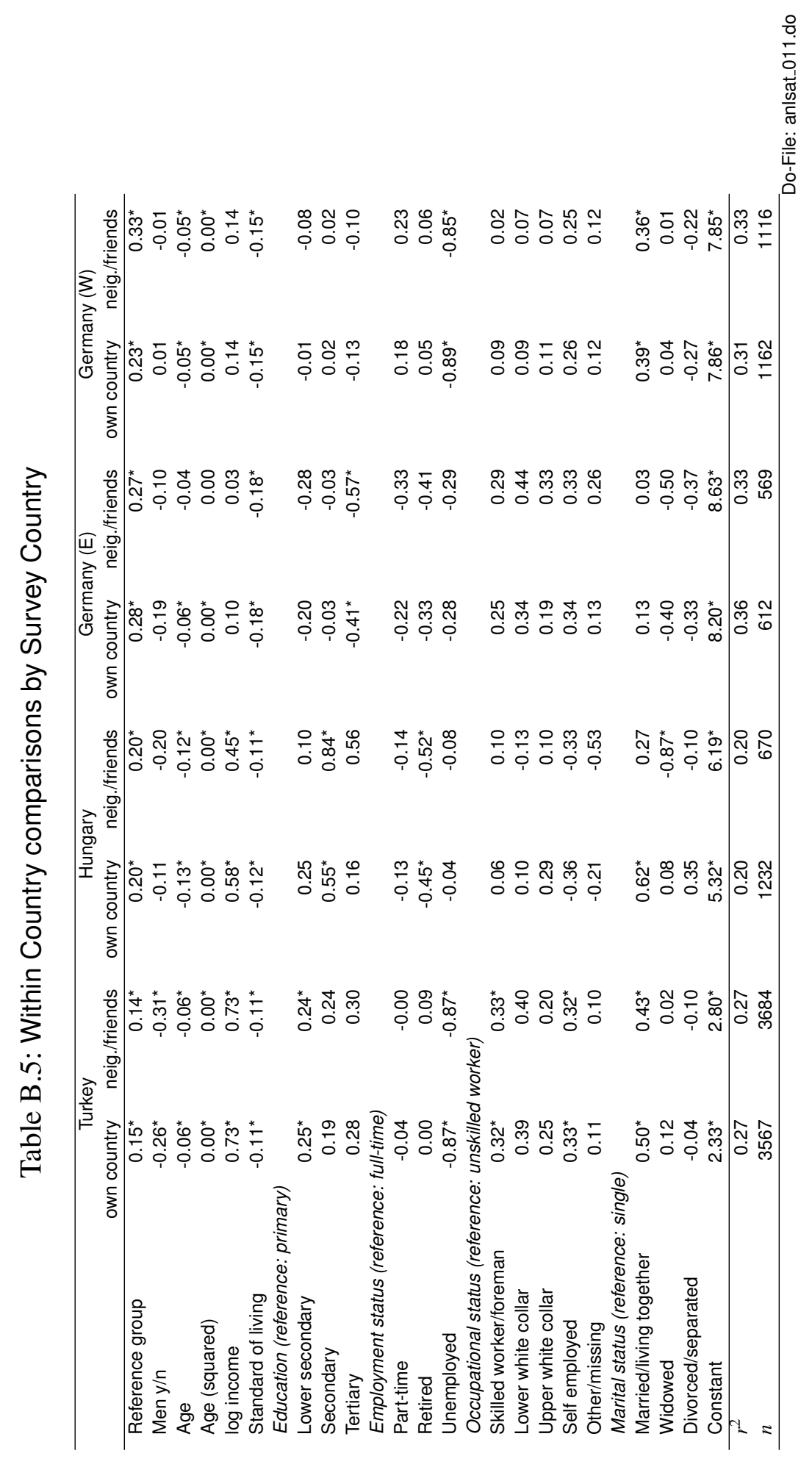




\section{B.2 Regression models for section 4.4}

Table B.6: Cross-national comparison - Turkey

\begin{tabular}{|c|c|c|c|c|c|c|c|c|}
\hline & \multicolumn{8}{|c|}{ Reference country } \\
\hline & PL & HU & ES & IT & $\mathrm{FR}$ & SW & $\mathrm{NL}$ & $\mathrm{CH}$ \\
\hline Coef. reference country & $0.29^{*}$ & $0.28^{*}$ & $0.32^{*}$ & $0.34^{*}$ & $0.36^{*}$ & $0.35^{\star}$ & $0.38^{*}$ & $0.37^{\star}$ \\
\hline Upward comparison & -0.08 & -0.13 & 0.02 & -0.29 & $-0.48^{*}$ & $-0.57^{*}$ & $-0.62^{*}$ & $-0.82^{*}$ \\
\hline Ref. country * upward comp. & $-0.16^{*}$ & -0.07 & $-0.23^{*}$ & $-0.33^{*}$ & $-0.29^{*}$ & $-0.28^{*}$ & $-0.35^{*}$ & $-0.30^{*}$ \\
\hline Men $y / n$ & -0.20 & $-0.36^{*}$ & $-0.23^{*}$ & -0.19 & -0.21 & $-0.26^{*}$ & $-0.25^{*}$ & $-0.23^{*}$ \\
\hline Age & $-0.08^{*}$ & $-0.07^{\star}$ & $-0.06^{*}$ & $-0.07^{*}$ & $-0.06^{*}$ & $-0.05^{\star}$ & $-0.05^{*}$ & $-0.05^{\star}$ \\
\hline Age (squared) & $0.00^{*}$ & $0.00^{*}$ & $0.00^{*}$ & $0.00^{*}$ & $0.00^{*}$ & $0.00^{*}$ & $0.00^{*}$ & $0.00^{*}$ \\
\hline log income & $0.64^{*}$ & $0.62^{*}$ & $0.57^{\star}$ & $0.58^{*}$ & $0.58^{*}$ & $0.54^{*}$ & $0.54^{*}$ & $0.57^{*}$ \\
\hline Standard of living & $-0.08^{\star}$ & $-0.09^{*}$ & $-0.07^{\star}$ & $-0.08^{*}$ & $-0.07^{\star}$ & $-0.08^{*}$ & $-0.08^{*}$ & $-0.08^{*}$ \\
\hline \multicolumn{9}{|c|}{ Education (reference: primary) } \\
\hline Lower secondary & 0.21 & 0.20 & 0.19 & 0.12 & 0.09 & 0.19 & 0.11 & 0.11 \\
\hline Secondary & 0.14 & 0.04 & 0.13 & 0.14 & 0.18 & 0.18 & 0.14 & 0.19 \\
\hline Tertiary & 0.24 & 0.11 & 0.23 & 0.23 & $0.33^{*}$ & $0.34^{*}$ & 0.22 & $0.33^{*}$ \\
\hline \multicolumn{9}{|c|}{ Employment status (reference: full-time) } \\
\hline Part-time & 0.00 & -0.06 & -0.09 & -0.03 & -0.06 & -0.16 & -0.14 & -0.15 \\
\hline Retired & -0.00 & -0.01 & -0.01 & 0.02 & 0.05 & -0.06 & 0.01 & 0.01 \\
\hline Unemployed & $-0.60^{*}$ & $-0.67^{\star}$ & $-0.64^{*}$ & $-0.56^{*}$ & $-0.54^{\star}$ & $-0.58^{\star}$ & $-0.57^{\star}$ & $-0.59^{*}$ \\
\hline \multicolumn{9}{|c|}{ Occupational status (reference: unskilled worker) } \\
\hline Skilled worker/foreman & 0.21 & 0.22 & 0.24 & 0.24 & 0.25 & 0.24 & 0.28 & 0.28 \\
\hline Lower white collar & 0.28 & 0.25 & 0.19 & 0.22 & 0.22 & 0.17 & 0.20 & 0.24 \\
\hline Upper white collar & 0.17 & 0.10 & 0.09 & 0.07 & 0.10 & 0.07 & 0.12 & 0.11 \\
\hline Self employed & $0.33^{*}$ & 0.27 & $0.30^{*}$ & $0.29^{*}$ & $0.32^{*}$ & 0.24 & 0.26 & $0.28^{*}$ \\
\hline Other/missing & 0.07 & -0.02 & 0.03 & 0.06 & 0.10 & -0.06 & 0.03 & 0.05 \\
\hline \multicolumn{9}{|c|}{ Marital status (reference: single) } \\
\hline Married/living together & $0.68^{*}$ & $0.55^{*}$ & $0.46^{*}$ & $0.49^{*}$ & $0.50^{*}$ & $0.46^{\star}$ & $0.39^{*}$ & $0.41^{*}$ \\
\hline Widowed & 0.17 & 0.18 & 0.09 & 0.26 & 0.19 & 0.16 & 0.23 & 0.18 \\
\hline Divorced/separated & 0.42 & 0.30 & 0.28 & 0.33 & 0.23 & 0.22 & 0.21 & 0.22 \\
\hline Constant & $3.62^{*}$ & $3.90^{*}$ & $4.31^{*}$ & $4.63^{*}$ & $4.55^{\star}$ & $4.75^{\star}$ & $4.98^{*}$ & $4.87^{\star}$ \\
\hline$r^{2}$ & 0.31 & 0.33 & 0.33 & 0.35 & 0.35 & 0.35 & 0.36 & 0.36 \\
\hline$n$ & 3147 & 3155 & 3181 & 3240 & 3260 & 3215 & 3269 & 3242 \\
\hline
\end{tabular}


Table B.7: Cross-national comparison - Hungary

\begin{tabular}{|c|c|c|c|c|c|c|c|c|}
\hline & \multicolumn{8}{|c|}{ Reference country } \\
\hline & PL & $\mathrm{HU}$ & ES & IT & $\mathrm{DE}$ & FR & SV & NL \\
\hline Coef. reference country & -0.04 & $0.27^{\star}$ & $0.35^{\star}$ & $0.40^{*}$ & $0.32^{*}$ & $0.42^{*}$ & $0.35^{\star}$ & $0.42^{*}$ \\
\hline Upward comparison & 0.35 & -0.21 & -0.21 & -0.34 & -0.03 & -0.00 & -0.32 & $-0.85^{*}$ \\
\hline Ref. country * upward comp. & 0.28 & -0.02 & -0.14 & -0.34 & -0.16 & $-0.94^{*}$ & 0.09 & $-0.47^{*}$ \\
\hline Men y/n & -0.01 & -0.01 & 0.04 & 0.03 & 0.06 & 0.02 & 0.01 & 0.00 \\
\hline Age & $-0.12^{*}$ & $-0.12^{*}$ & $-0.11^{*}$ & $-0.10^{*}$ & $-0.11^{*}$ & $-0.09^{*}$ & $-0.11^{*}$ & $-0.09^{*}$ \\
\hline Age (squared) & $0.00^{*}$ & $0.00^{*}$ & $0.00^{*}$ & $0.00^{*}$ & $0.00^{*}$ & $0.00^{*}$ & $0.00^{*}$ & $0.00^{*}$ \\
\hline log income & $0.71^{*}$ & $0.45^{\star}$ & $0.46^{*}$ & $0.46^{*}$ & $0.49^{*}$ & $0.40^{*}$ & $0.49^{*}$ & $0.42^{*}$ \\
\hline Standard of living & $-0.09^{\star}$ & $-0.10^{\star}$ & $-0.09^{*}$ & $-0.08^{*}$ & $-0.08^{*}$ & $-0.07^{*}$ & $-0.07^{*}$ & $-0.07^{*}$ \\
\hline \multicolumn{9}{|c|}{ Education (reference: primary) } \\
\hline Lower secondary & 0.11 & 0.12 & 0.07 & 0.21 & 0.09 & -0.18 & -0.02 & 0.04 \\
\hline Secondary & 0.39 & 0.32 & 0.21 & 0.42 & 0.34 & 0.18 & 0.40 & 0.33 \\
\hline Tertiary & -0.08 & 0.05 & -0.11 & 0.06 & 0.08 & -0.13 & 0.08 & -0.01 \\
\hline \multicolumn{9}{|c|}{ Employment status (reference: full-time) } \\
\hline Part-time & -0.08 & -0.21 & -0.21 & -0.23 & -0.13 & -0.30 & -0.10 & -0.20 \\
\hline Retired & -0.18 & -0.27 & -0.28 & -0.25 & -0.13 & -0.16 & -0.20 & -0.33 \\
\hline Unemployed & 0.21 & -0.23 & -0.12 & 0.01 & -0.11 & -0.05 & -0.18 & -0.12 \\
\hline \multicolumn{9}{|c|}{ Occupational status (reference: unskilled worker) } \\
\hline Skilled worker/foreman & 0.24 & 0.07 & 0.15 & 0.02 & 0.02 & 0.07 & -0.08 & -0.03 \\
\hline Lower white collar & 0.22 & 0.11 & 0.18 & 0.05 & 0.11 & 0.07 & 0.10 & 0.13 \\
\hline Upper white collar & 0.44 & 0.23 & 0.35 & 0.18 & 0.24 & 0.23 & 0.22 & 0.21 \\
\hline Self employed & 0.02 & -0.37 & -0.36 & -0.42 & -0.37 & -0.23 & -0.34 & -0.37 \\
\hline Other/missing & -0.14 & -0.31 & -0.25 & -0.41 & -0.31 & -0.06 & -0.32 & -0.27 \\
\hline \multicolumn{9}{|l|}{ Marital status (reference: single) } \\
\hline Married/living together & $0.48^{*}$ & $0.49^{*}$ & $0.64^{*}$ & $0.56^{*}$ & $0.49^{*}$ & $0.56^{*}$ & $0.52^{*}$ & $0.50^{*}$ \\
\hline Widowed & 0.15 & -0.01 & 0.11 & 0.07 & -0.08 & 0.10 & 0.08 & -0.10 \\
\hline Divorced/separated & 0.16 & 0.22 & 0.34 & 0.39 & 0.18 & 0.38 & 0.30 & 0.21 \\
\hline Constant & $3.84^{*}$ & $6.77^{\star}$ & $6.72^{*}$ & $7.15^{\star}$ & $6.57^{\star}$ & $7.41^{*}$ & $6.80^{*}$ & $7.45^{*}$ \\
\hline$r^{2}$ & 0.20 & 0.22 & 0.24 & 0.28 & 0.24 & 0.28 & 0.26 & 0.28 \\
\hline$n$ & 1019 & 1008 & 1064 & 1139 & 1079 & 1064 & 1069 & 1114 \\
\hline
\end{tabular}


Table B.8: Cross-national comparison - Germany (E)

\begin{tabular}{|c|c|c|c|c|c|c|c|c|}
\hline & \multicolumn{8}{|c|}{ Reference country } \\
\hline & PL & $\mathrm{HU}$ & ES & IT & $\mathrm{DE}(\mathrm{W})$ & FR & NL & $\mathrm{CH}$ \\
\hline Coef. reference country & 0.20 & 0.17 & 0.20 & 0.20 & $0.43^{*}$ & $0.53^{*}$ & $0.48^{*}$ & $0.47^{*}$ \\
\hline Upward comparison & 0.56 & 0.60 & 0.28 & 0.40 & -0.02 & -0.39 & -0.23 & -0.19 \\
\hline Ref. country * upward comp. & 0.05 & 0.02 & 0.03 & 0.01 & $-0.46^{*}$ & $-0.37^{*}$ & $-0.31^{*}$ & $-0.41^{*}$ \\
\hline Men y/n & -0.14 & -0.13 & -0.14 & -0.14 & -0.17 & -0.09 & -0.19 & -0.06 \\
\hline Age & -0.04 & $-0.06^{*}$ & -0.04 & -0.04 & $-0.05^{\star}$ & -0.04 & -0.03 & -0.04 \\
\hline Age (squared) & 0.00 & $0.00^{*}$ & 0.00 & 0.00 & $0.00^{*}$ & 0.00 & 0.00 & 0.00 \\
\hline log income & -0.00 & 0.02 & -0.02 & -0.12 & -0.04 & -0.01 & -0.17 & 0.05 \\
\hline \multicolumn{9}{|l|}{ Education (reference: primary) } \\
\hline Lower secondary & -0.17 & -0.21 & -0.18 & -0.16 & -0.25 & -0.12 & -0.23 & -0.28 \\
\hline Secondary & -0.04 & -0.10 & -0.12 & -0.07 & -0.16 & 0.09 & -0.03 & -0.21 \\
\hline Tertiary & -0.36 & $-0.42^{*}$ & $-0.46^{*}$ & -0.42 & $-0.57^{*}$ & -0.32 & $-0.42^{*}$ & $-0.61^{*}$ \\
\hline \multicolumn{9}{|c|}{ Employment status (reference: full-time) } \\
\hline Part-time & -0.19 & -0.26 & -0.16 & -0.18 & -0.22 & -0.12 & -0.17 & -0.13 \\
\hline Retired & -0.27 & -0.27 & -0.35 & $-0.46^{\star}$ & -0.38 & -0.39 & -0.39 & $-0.51^{*}$ \\
\hline Unemployed & -0.24 & -0.25 & -0.20 & -0.24 & -0.24 & -0.22 & -0.33 & -0.28 \\
\hline \multicolumn{9}{|c|}{ Occupational status (reference: unskilled worker) } \\
\hline Skilled worker/foreman & 0.30 & 0.23 & 0.29 & 0.25 & 0.34 & 0.25 & 0.29 & 0.32 \\
\hline Lower white collar & 0.45 & 0.37 & 0.31 & 0.30 & 0.35 & 0.26 & 0.29 & 0.45 \\
\hline Upper white collar & 0.33 & 0.34 & 0.26 & 0.23 & 0.32 & 0.14 & 0.29 & 0.37 \\
\hline Self employed & 0.45 & 0.37 & 0.40 & 0.39 & 0.32 & 0.34 & 0.45 & 0.51 \\
\hline Other/missing & 0.26 & 0.25 & 0.11 & 0.12 & 0.20 & 0.12 & 0.20 & 0.27 \\
\hline \multicolumn{9}{|l|}{ Marital status (reference: single) } \\
\hline Married/living together & -0.10 & 0.09 & -0.06 & -0.09 & 0.20 & -0.12 & 0.09 & 0.05 \\
\hline Widowed & -0.43 & -0.18 & -0.34 & -0.41 & -0.32 & -0.19 & -0.22 & -0.04 \\
\hline Divorced/separated & $-0.56^{\star}$ & -0.37 & -0.36 & $-0.51^{*}$ & -0.18 & -0.30 & -0.21 & -0.18 \\
\hline Constant & $7.36^{\star}$ & $7.90^{*}$ & $8.47^{*}$ & $9.19^{*}$ & $9.77^{*}$ & $9.18^{*}$ & $10.18^{*}$ & $8.97^{*}$ \\
\hline$r^{2}$ & 0.39 & 0.38 & 0.37 & 0.37 & 0.40 & 0.41 & 0.44 & 0.46 \\
\hline$n$ & 574 & 549 & 512 & 531 & 607 & 530 & 537 & 552 \\
\hline
\end{tabular}


Table B.9: Cross-national comparison - Germany (W)

\begin{tabular}{|c|c|c|c|c|c|c|c|c|}
\hline & \multicolumn{8}{|c|}{ Reference country } \\
\hline & PL & $\mathrm{HU}$ & ES & IT & $\mathrm{DE}(\mathrm{E})$ & FR & NL & $\mathrm{CH}$ \\
\hline Coef. reference country & 0.17 & $0.57^{*}$ & $0.44^{*}$ & $0.43^{*}$ & 0.16 & $0.43^{*}$ & $0.35^{\star}$ & $0.39^{*}$ \\
\hline Upward comparison & -0.15 & -0.46 & -0.14 & -0.22 & 0.25 & $-0.37^{\star}$ & -0.01 & -0.10 \\
\hline Ref. country * upward comp. & 0.08 & -0.37 & -0.21 & -0.18 & 0.02 & $-0.18^{*}$ & -0.16 & $-0.15^{\star}$ \\
\hline Men $y / n$ & -0.01 & -0.03 & 0.00 & 0.00 & -0.00 & 0.01 & -0.01 & -0.00 \\
\hline Age & $-0.07^{\star}$ & $-0.07^{*}$ & $-0.07^{\star}$ & $-0.07^{\star}$ & $-0.06^{*}$ & $-0.06^{*}$ & $-0.06^{\star}$ & $-0.04^{*}$ \\
\hline Age (squared) & $0.00^{*}$ & $0.00^{*}$ & $0.00^{*}$ & $0.00^{*}$ & $0.00^{*}$ & $0.00^{*}$ & $0.00^{*}$ & $0.00^{*}$ \\
\hline log income & 0.17 & 0.20 & 0.20 & 0.18 & 0.17 & 0.19 & 0.21 & 0.11 \\
\hline Standard of living & $-0.14^{*}$ & $-0.14^{*}$ & $-0.12^{*}$ & $-0.13^{*}$ & $-0.15^{\star}$ & $-0.13^{*}$ & $-0.11^{*}$ & $-0.11^{*}$ \\
\hline \multicolumn{9}{|l|}{ Education (reference: primary) } \\
\hline Lower secondary & -0.04 & -0.04 & -0.03 & 0.00 & -0.04 & -0.00 & 0.05 & -0.00 \\
\hline Secondary & 0.02 & -0.02 & 0.03 & -0.01 & -0.01 & 0.00 & 0.11 & 0.07 \\
\hline Tertiary & -0.05 & -0.08 & -0.02 & -0.06 & -0.13 & -0.08 & -0.01 & -0.15 \\
\hline \multicolumn{9}{|c|}{ Employment status (reference: full-time) } \\
\hline Part-time & 0.17 & 0.15 & 0.16 & 0.14 & 0.14 & 0.14 & 0.20 & 0.23 \\
\hline Retired & 0.03 & 0.03 & 0.02 & 0.03 & 0.07 & 0.05 & 0.04 & 0.07 \\
\hline Unemployed & $-0.89^{*}$ & $-0.94^{*}$ & $-0.74^{*}$ & $-0.78^{\star}$ & $-0.90^{*}$ & $-0.74^{*}$ & $-0.82^{*}$ & $-0.84^{*}$ \\
\hline \multicolumn{9}{|c|}{ Occupational status (reference: unskilled worker) } \\
\hline Skilled worker/foreman & 0.08 & 0.04 & 0.12 & 0.03 & 0.08 & 0.11 & 0.09 & 0.08 \\
\hline Lower white collar & 0.03 & 0.05 & 0.11 & 0.08 & 0.11 & 0.09 & 0.02 & 0.02 \\
\hline Upper white collar & 0.08 & 0.10 & 0.09 & 0.09 & 0.12 & 0.09 & 0.06 & 0.16 \\
\hline Self employed & 0.20 & 0.27 & 0.38 & 0.33 & 0.23 & 0.30 & 0.31 & 0.27 \\
\hline Other/missing & 0.13 & 0.10 & 0.10 & 0.12 & 0.14 & 0.13 & 0.07 & 0.08 \\
\hline \multicolumn{9}{|l|}{ Marital status (reference: single) } \\
\hline Married/living together & $0.43^{*}$ & $0.50^{*}$ & $0.49^{*}$ & $0.42^{*}$ & $0.43^{*}$ & $0.42^{*}$ & $0.38^{*}$ & $0.35^{*}$ \\
\hline Widowed & -0.03 & -0.04 & 0.09 & 0.01 & 0.06 & -0.02 & -0.07 & -0.13 \\
\hline Divorced/separated & -0.21 & -0.12 & -0.09 & -0.23 & -0.19 & -0.21 & -0.20 & -0.21 \\
\hline Constant & $7.13^{*}$ & $7.65^{\star}$ & $7.52^{*}$ & $7.81^{*}$ & $7.37^{\star}$ & $7.94^{*}$ & $7.46^{*}$ & $8.28^{*}$ \\
\hline$r^{2}$ & 0.34 & 0.34 & 0.35 & 0.36 & 0.31 & 0.35 & 0.35 & 0.38 \\
\hline$n$ & 1117 & 1106 & 1108 & 1112 & 1144 & 1117 & 1117 & 1125 \\
\hline
\end{tabular}




\section{Bibliography}

Akçay, A. A. (2005): Desires and realities: a cross-national study of expected standard of living and actual situation., unpublished Manuscript, Department of Sociology, Metu, Turkey.

Alber, J., Fahey, T. (2004): Perceptions of living conditions in an enlarged Europe. Luxembourg: European Foundation for the Improvement of Living and Working Conditions, Office for Official Publications of the European Communities (http://www.eurofound.eu.int/publications/EF03113EN.pdf).

Alesina, A., Di Tella, R., MacCulloch, R. (2001): Inequality and happiness: are Europeans and Americans different? NBER Working Paper No. 8198. Cambridge, MA: National Bureau of Economic Research.

Argyle, M. (1999): Causes and correlates of happiness. In Kahnemann, D., Diener, E., Schwarz, N., eds., Well-Being: The Foundations of Hedonic Psychology, New York: Russell Sage, pp. 353-373.

Beck, U. (2002): The cosmopolitan society and its enemies. British Journal for Sociology, 51, 79106.

Beck, U., Grande, E. (2004): Das kosmopolitische Europa. Frankfurt a. M.: Suhrkamp Verlag.

Blau, P. M. (1977): Inequality and heterogeneity. A primitive theory of social structure. New York: The Free Press.

Buchanan, W., Cantril, H. (1953): How nations see each other. Urbana: University of Illinois Press.

Campbell, A., Convers, P. E., Rodgers, W. L. (1976): The quality of American life. Perceptions, evaluations, and satisfactions. New York: Russel Sage Foundation.

Christoph, B., Noll, H.-H. (2003): Subjective well-being in the european union during the 90s. Social Indicators Research, 64(3), 521-546.

Cleveland, W. S. (1994): The elements of graphing data. 2 edition, Summit: Hobart Press.

Cummins, R. A. (2002): Subjective well-being from rich and poor. In Glatzer, W., ed., Rich and poor, Dordrecht usw.: Kluwer, pp. 137-156.

Delhey, J. (2004): Life Satisfaction in the Enlarged Europe. Luxembourg: European Foundation for the Improvement of Living and Working Conditions, Office for Official Publications of the European Communities (http://www.eurofound.eu.int/publications/EF0437EN.pdf).

Delhey, J., Böhnke, P., Habich, R., Zapf, W. (2002): Quality of life in a European perspective. the Euromodule as a new instrument for comparative welfare research. Social Indicators Research.

Diener, E., Sandvik, E., Seidlitz, L., Diener, M. (1992): The relationship between income and subjective well-being: relative or absulute? Social Indicators Research, 28(3), 195-223.

Diener, E., Suh, E., Lucas, R., Smith, H. (1999): Subjective well-being: Three decades of progress. Psycholgocial Bulletin, 125, 276-302.

Easterlin, R. A. (1974): Does economic growth improve the human lot? Some empirical evidence. In David, P. A., Reder, M. W., eds., Nations and households in economic growth: Essays in honour of Moses Abramowitz, New York and London: Academic Press, pp. 89-125.

Fahey, T. (2005): Rich and poor in the enlarged EU: an expanded approach to measurement. Dublin: 
European Foundation for the Improvement of Living and Working Conditions.

Fahey, T., Smyth, E. (2003): What can subjective indicators tell us about inequalities in welfare? Evidence from 33 European societies. Dublin: The Economic and Social Research Institute.

Feld, S. L. (1982): Social structural determinants of similarity among associates. American Sociological Review, 47, 797-801.

Festinger, L. (1968): A theory of social comparisons. In Hyman, H. H., Singer, E., eds., Readings in reference group theory and research, New York: The Free Press, pp. 123-146.

Frey, B. S., Stutzer, A. (2002): What can economists learn from happiness research? Journal of Economic Literature, 40(2), 402-435.

Ger, G., Belk, R. W. (1996): Cross-cultural differences in materialism. Journal of Economic Psychology, 17, 55-77.

Goldthorpe, J. H. (2001): Causation, statistics, and sociology. European Sociological Review, 17(1), $1-20$.

Hagerty, M. R. (1998): Unifying livability and comparison theory: Cross-national time-series analysis of life-satisfaction. Social Indicators Research, 47, 343-356.

Heidenreich, M. (2003): Regional inequalities in the enlarged Euroland. Journal of European Social Policy, 13(4), 313-333.

Hyman, H. H. (1968): Introduction. In Hyman, H. H., Singer, E., eds., Readings in reference group theory and research, New York: The Free Press, pp. 3-21.

Inglehart, R. (1990): Culture shift in advanced industrial society. Princeton: Princeton University Press.

Jackson, R. M. (1977): Social structure and process in friendship choice. In Fischer, C. S., Jackson, R. M., Stueve, C. A., Gerson, K., Lynne, M. J., Baldassare, M., eds., Network and places. Social relations in the urban setting, New York: Free Press, pp. 59-78.

Kelly, H. H. (1968): Two functions of reference groups. In Hyman, H. H., Singer, E., eds., Readings in reference group theory and research, New York: The Free Press, pp. 199-206.

Keyfitz, N. (1992): Development and the elimination of poverty. Economic Development and Cultural Change, 30, 649-670.

Mau, S. (2004): Soziale Ungleichheit in der Europäischen Union. Aus Politik und Zeitgeschichte, B $38,38-46$.

Mead, G. H. (1934): Mind, self and society. Chicago: University of Chicago Press.

Merton, R. K., Kitt, A. S. (1950): Contributions to the theory of reference group behaviour. In Merton, R. K., Lazarsfeld, P. F., eds., Studies in the scope and method of 'The American Soldier', Glencoe: The Free Press, pp. 40-106.

Michalos, A. (1985): Multiple discrepancies theory (MDT). Social Indicators Research, 16, 347-413.

Schwarz, N., Strack, F. (1999): Reports of subjective well-being: judgemental processes and their methodological implications. In Kahnemann, D., Diener, E., Schwarz, N., eds., Well-being: the foundations of hedonic psychology, New York: Sage, pp. 353-373.

Schyns, P. (2002): Wealth of nations, individual income and life satisfaction in 42 countries: A multilevel approach. Social Indicators Research, 60(1-3), 5-40.

Stern, E., Keller, S. (1968): Spontaneous group references in France. In Hyman, H. H., Singer, E., eds., Readings in reference group theory and research, New York: The Free Press, pp. 199-206. 
Stouffer, S. A., Suchman, E. A., DeVinney, L. C., Star, S. A., M., W. R. (1949): The American soldier: adjustment during army life. Princeton: Princeton University Press.

Veenhoven, R. (1991): Is happiness relative? Social Indicators Research, 24, 1-34.

Veenhoven, R. (1999): Quality-of-life in individualistic society. Social Indicators Research, 48, 157186.

Zapf, W. (2000): How to evaluate German unification, WZB Discussion Papers FS III 00-404. 
New since 2003:

The Research Area I - Employment, Social Structure, and Welfare State

(ARS) was established January 1, 2003. It comprises the Research Units

Labour Market Policy and Employment (AB), Inequality and Social

Integration (USI) and the Working Group Public Health (PH).

Research Unit

Inequality and Social

Integration

\section{Discussion Papers 2003}

Harold L. Wilensky

Postindustrialism and

Postmaterialism? A Critical View of the

"New Economy", the "Information

Age", the "High Tech Society", and All

That

Order No.: SP I 2003 - 201

Wilhelm Hinrichs

Ausländische Bevölkerungsgruppen in Deutschland. Integrationschancen 1985 und 2000

Order No.: SP I 2003 - 202

\section{Discussion Papers 2004}

\section{Jan Delhey}

European Social Integration.

From convergence of countries to transnational relations between people

Order No.: SP I 2004 - 201

Jan Delhey, Kenneth Newton

Social Trust: Global Pattern or Nordic

Exceptionalism?

Order No.: SP I 2004 - 202

\section{Ulrich Kohler}

Empirische Untersuchung zweier Individualisierungshypothesen mit Querschnittsdaten aus 28 Ländern Order No.: SP I 2004 - 203
Discussion Papers 2005

Ricarda Nauenburg

Globalisierung und rechtspopulistische Wahlerfolge

Order No.: SP | 2005 - 201

Eckhard Priller, Jana Sommerfeld Wer spendet in Deutschland? Eine sozialstrukturelle Analyse Order No.: SP | 2005 - 202

Jan Delhey

A trade-off between enlargement and integration? An analysis of trust between EU nationalities

Order No.: SP I 2005 - 203

Jan Delhey, Urlich Kohler From Nationally Bounded to PanEuropean Inequalities? On the Importance of Foreign Countries as Reference Groups

Order No.: SP I 2005 - 204 
WZB Forschungsschwerpunkt I „Arbeit, Sozialstruktur und Sozialstaat“ Research Area "Employment, Social Structure, and Welfare State"

Abteilung „Ungleichheit und soziale Integration“ (vormals Abt. „Sozialstruktur und Sozialberichterstattung“) Research Unit “Inequality and Social Integration” (former Research Unit “Social Structure and Social Reporting”)

\section{Discussion Papers (Stand: August 2003)}

FS III 98-401

FS III 98-402

FS III 98-403

FS III 98-404

FS III 98-405

FS III 98-406

FS III 98-407

FS III 99-401

FS III 99-402

FS III 99-403

FS III 99-404

FS III 99-405

FS III 99-406

FS III 99-407

FS III 99-408

FS III 99-409

FS III 99-410
Inequality and Support for Redistributive Policy: One World of Post-Communism, Two Worlds of Western Capitalism?

Jan Delhey

Über die Möglichkeit einer kontinuierlichen und zügigen Fortsetzung des chinesischen Modernisierungsprozesses

Li Pengcheng

Lebensstile im Zeitvergleich: Typologien für West- und Ostdeutschland 1993 und 1996 Annette Spellerberg und Regina Berger Schmitt

Teilzeitbeschäftigte in Europa. Arbeitsbedingungen, Familienkontext, Motive und subjektive Bewertungen

Karin Schulze Buschoff und Jana Rückert

Das Erwerbsverhalten von Frauen im europäischen Vergleich. Welche Faktoren

beeinflussen Arbeitszeiten und Arbeitszeitwünsche?

Karin Schulze Buschoff, Inge Weller und Jana Rückert

Rette sich, wer kann? Die Krise der gesetzlichen Rentenversicherung und die Privatisierung der Altersvorsorge

Thomas Bulmahn

Taking Stock: German Unification as Reflected in the Social Sciences Thomas Bulmahn

Wohnsuburbanisierung am Beispiel Berlin. Ein Erklärungsrahmen Wilhelm Hinrichs

Income Dynamics in Three Societies. An investigation of social dynamics using "old" and "new" types of social indicators

Zsolt Spéder, Roland Habich

Inequality and Attitudes. Postcommunism, Western Capitalism and Beyond Jan Delhey

Social Reporting in the 1970s and 1990s

Wolfgang Zapf

New Structures of Inequality. Some Trends of Social Change in Modernized Societies Heinz-Herbert Noll

Teilzeitarbeit in Schweden, Großbritannien und Deutschland. Individuelle Dynamik und Haushaltskontext im Ländervergleich

Karin Schulze Buschoff unter Mitarbeit von Jana Rückert-John

Komparative und nicht-komperative Ansätze zur Analyse der Europäisierung der

Sozialstrukturen

Bernhard Schäfers

Lebensstandard und Armut im vereinten Deutschland

Petra Böhnke, Jan Delhey

Entwicklung der Wohnverhältnisse in Ost- und Westdeutschland Wilhelm Hinrichs

Demokratieentwicklung und Mitwirkung in Ostdeutschland

Eckhard Priller 
FS III 99-411

FS III 99-412

FS III 99-413

FS III 00-402

FS III 00-403

FS III 00-404

FS III 01-401

FS III 01-402

FS III 01-403

FS III 01-404

FS III 01-405

FS III 01-406

FS III 01-407

FS III 02-401

FS III 02-402

FS III 02-403

FS III 02-404
Attribute einer lebenswerten Gesellschaft: Freiheit, Wohlstand, Sicherheit und Gerechtigkeit Thomas Bulmahn

Über die materielle zur inneren Einheit? Wohlstandslagen und subjektives Wohlbefinden in Ost- und Westdeutschland Jan Delhey, Petra Böhnke

Poverty in a Multidimensional Perspective. Great Britain and Germany in Comparison Petra Böhnke, Jan Delhey

Modernity and Happiness. The Case of Germany Thomas Bulmahn

Understanding Regime Support in New Democracies. Does Politics Really Matter More Than Economics Jan Delhey, Verena Tobsch

How to evaluate German unification? Wolfgang Zapf

The Euromodule. A New Instrument for Comparative Welfare Research Jan Delhey, Petra Böhnke, Roland Habich, Wolfgang Zapf

Nothing Left to Lose? Poverty and Social Exclusion in Comparison. Empirical Evidence on Germany Petra Böhnke

The Prospects of Catching Up for New EU Members. Lessons for the Accession Countries to the European Union from Previous Enlargements Jan Delhey

Why Social Policy Needs Subjective Indicators Ruut Veenhoven

Patterns of Popular Support for the Welfare State. A Comparison of the United Kingdom and Germany Steffen Mau

Social Cleavages and Political Conflicts in the Contemporary Czech Society Pavel Machonin

Reporting on Social Exclusion: Standard of Living and Social Participation in Hungary, Spain, and Germany

Petra Böhnke

Korruption in Bewerberländern zur Europäischen Union. Institutionenqualität und Korruption in vergleichender Perspektive Jan Delhey

Who Trusts? The Origins of Social Trust in Seven Nations Jan Delhey, Kenneth Newton

Zur Entwicklung der privaten Altersvorsorge. Vorsorgebereitschaft, Vorsorgeniveau und erwartete Absicherung im Alter Thomas Bulmahn

Entwicklungen der deutschen Lebensqualität - die Bundesländer im Vergleich Denis Huschka 
Absender / Return Address:

Wissenschaftszentrum Berlin

für Sozialforschung

Presse- und Informationsreferat

Reichpietschufer 50

D-10785 Berlin-Tiergarten

Hiermit bestelle ich folgende(s)

Discussion paper(s):

Bestell-Nr. / Order no.
Please send me the following

Discussion paper(s):

Autor/in, Kurztitel / Author(s) / Title(s) in brief 